Preprints of the

Max Planck Institute for

Research on Collective Goods

Bonn 2010/05

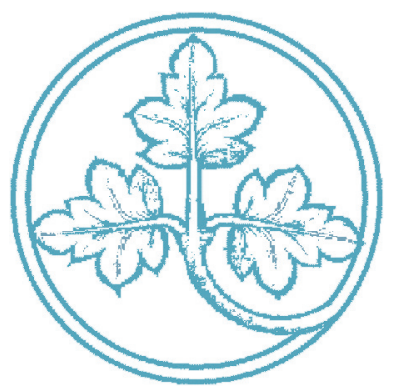

Competition, Risk-Shifting, and Public Bail-out Policies

Reint Gropp

Hendrik Hakenes

Isabel Schnabel

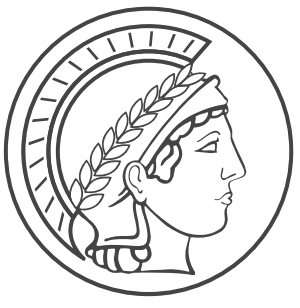




\section{Competition, Risk-Shifting, and Public Bail-out Policies}

Reint Gropp / Hendrik Hakenes / Isabel Schnabel

January 2010 


\title{
Competition, Risk-Shifting, and Public Bail-out Policies*
}

\author{
Reint Gropp ${ }^{\dagger}$ \\ European Business School, CFS, and ZEW \\ Hendrik Hakenes \\ University of Hannover and MPI Bonn \\ Isabel Schnabel \\ University of Mainz, MPI Bonn, and CEPR
}

January 14,2010

\footnotetext{
*We thank an anonymous referee, Franklin Allen, Carsten Burhop, Hans Degryse, Christoph Engel, Georg Gebhardt, Timothy Guinnane, Christian Hellwig, Martin Hellwig, Bernd Rudolph, Laurence Scialom, Mathew Spiegel and Wolf Wagner for helpful comments. We would like to thank Sandrine Corvoisier for helping us to compile the data set and Silvia Grätz, Leonie Gerhards, and Tobias Körner for excellent research assistance. Moreover, we have benefited from the comments of seminar participants at the Max Planck Institute in Bonn, the University of Zürich, the University of Mannheim, Humboldt University of Berlin, the University of Bonn, the ECB-CFS-Bundesbank joint lunch-time seminar in Frankfurt, the University Paris X at Nanterre, Tilburg University, the Austrian National Bank in Vienna, and the Federal Reserve Bank in San Francisco, as well as of conference participants of the SFB/TR 15 Meeting in Frauenwörth, the annual meeting of the German Economic Association in Bayreuth, the ProBanker Symposium in Maastricht, the annual meeting of the German Finance Association in Dresden, the annual meeting of the European Economic Association in Budapest, the Sveriges Riksbank conference on "The Evolution of Financial Markets and Financial Institutions: New Threats to Financial Stability," and the RFS-Yale Conference on the financial crisis.

${ }^{\dagger}$ Corresponding author. Department of Finance, Accounting and Real Estate, European Business School, Rheingaustr. 1, 65375 Oestrich-Winkel, Germany, Phone: +49-6723-69215, Fax: +49-6723-69208, E-mail: reint.gropp@ebs.edu.
} 


\title{
Competition, Risk-Shifting, and Public Bail-out Policies
}

\begin{abstract}
This paper empirically investigates the effect of government bail-out policies on banks outside the safety net. We construct a measure of bail-out perceptions by using rating information. From there, we construct the market shares of insured competitor banks for any given bank, and analyze the impact of this variable on banks' risk-taking behavior, using a large sample of banks from OECD countries. Our results suggest that government guarantees strongly increase the risk-taking of competitor banks. In contrast, there is no evidence that public guarantees increase the protected banks' risk-taking, except for banks that have outright public ownership. These results have important implications for the effects of the recent wave of bank bail-outs on banks' risk-taking behavior.
\end{abstract}

JEL: G21, G28, L53.

Keywords: Government bail-out, implicit and explicit government guarantees, banking competition, risk-taking. 


\section{Introduction}

It is a widely maintained hypothesis that public guarantees distort competition in the banking sector. The reason is that publicly guaranteed banks are able to refinance at more favorable terms than other banks because the protected banks' creditors expect to be compensated by the state if their bank is in danger of becoming insolvent. This line of arguments has, for example, been underlying the discussion at the European Commission about state aids to German public banks in the form of public guarantees. As is wellknown, the Commission concluded that such guarantees were not compatible with the EC Treaty, and hence have to be phased out since July 2005.

In a recent paper, Hakenes and Schnabel (2009) have shown that such competitive distortions may undermine financial stability because they provoke higher risk-taking by the protected banks' competitors. The theoretical argument is straightforward: Lower refinancing costs induce the protected bank to behave more aggressively (for example, by raising deposit rates or lowering loan rates). This increases competition and decreases margins, and hence charter values, for the competitor banks, and pushes these banks towards higher risk-taking.

While there is an extensive empirical literature examining the effect of bail-out policies on the risk-taking of protected banks, the effect of bail-out policies on banks outside the safety net has not - to our knowledge - been systematically examined. To fill this gap, this paper empirically investigates the relationship between banks' risk-taking behavior and the competitive distortions induced by public guarantees in the banking sector.

The definition of public guarantees employed in this paper is broad. It is not limited to explicit guarantees and public ownership, but also considers implicit guarantees. By 
implicit guarantees we mean the market expectation that a bank is saved even if there is no explicit government commitment to do so. This is important. Before the financial crisis, many countries have seen merger waves in their banking sectors, leading to high concentration ratios and an increasing number of "too big to fail" banks. Ultimately, this was reflected in the various rescue operations of private banks in most industrialized countries in the wake of the current financial crisis. As a consequence, most large banks presumably currently benefit from either explicit or implicit government guarantees. Hence, this paper speaks to the potential consequences of the recent bail-out policies around the world. The results presented in this paper suggest that if the bail-out policies increased market expectations of bail-outs in the future, this may distort competition, increase the risk-taking of all banks (whether protected or not), and ultimately may lead to greater financial instability in the future.

Implicit guarantees are inherently difficult to measure. In our empirical analysis, we make use of the fact that some of the big rating agencies publish ratings reflecting their expectations of the probability of external support. On the basis of this information, we construct a variable, called the market share of insured competitor banks (MSI), which captures the degree of competitive distortions through explicit or implicit guarantees, and we analyze the effect of this variable on banks' risk-taking.

Our regressions show that the presence of banks protected by government guarantees significantly increases the risk-taking of the competitor banks. This result is robust to a number of different specifications, including an instrumental variable model, in which we are able to trace the effect of $M S I$ through competition to risk-taking. They are also robust to using different book measures of bank risk-taking, including problem loan ratios, equity ratios, and liquidity ratios. In contrast, using the same set of measures for bank 
risk, there is no evidence that public guarantees increase the protected banks' risk-taking, except for banks with outright public ownership.

These results have important implications for crisis management. First, they suggest that banks' competitive conduct after the crisis may not be independent of government intervention during the crisis. This effect of government intervention operating through competition may be more important than the effect of government guarantees on the protected banks themselves. Second, the distortion induced by government intervention during the current crisis is not easily removed. Even if governments divest their bank ownership swiftly in the next few years, implicit guarantees may persist, as private sector participants may have revised their expectations of future government intervention based on the events during the crisis.

The paper proceeds as follows. We start by developing our major hypotheses in Section 2 . In the following section, we present the empirical model and describe the construction of the major variables used in the empirical analysis, as well as data sources. Section 4 contains the empirical results from the baseline regressions. In Section 5, we present the results from an instrumental variable model that takes the simultaneity of banks' risktaking and interest margins into account. Section 6 presents estimations based on a more flexible specification of bail-out probabilities. Section 7 analyzes the distinction between private and public ownership of banks. Section 8 concludes.

\section{Bail-out guarantees and risk-shifting}

Economists have long been concerned about the effects of explicit or implicit government bail-out guarantees on the protected banks' risk-taking. In theory, government bail-out 
guarantees can affect the risk-taking of protected banks through two channels:

1. Market discipline: Public guarantees reduce market discipline because creditors anticipate their bank's bail-out and therefore have lower incentives to monitor the bank's risk-taking or to demand risk premia for higher observed risk-taking (Flannery, 1998, Sironi, 2003, Gropp et al., 2006). This tends to increase the protected banks' risk-taking. The effect is similar to that discussed in the deposit insurance literature (Merton 1977). If depositors are protected by a guarantee, they will punish their bank less for risk-taking, reducing market discipline.

2. Charter values: Public guarantees also affect banks' risk-taking behavior through their effect on banks' margins and charter values. Keeley (1990) was the first to show that higher charter values decrease the incentives for excessive risk-taking, because the threat of losing future rents acts as a deterrent to risk-taking. Government bail-out guarantees result in higher charter values for protected banks due to lower refinancing costs. This tends to reduce the protected banks' risk-taking.

Hence, as argued by Cordella and Yeyati (2003) and by Hakenes and Schnabel (2009), the net effect of public bail-out guarantees on the risk-taking of protected banks is ambiguous and depends on the relative weight of the two channels. In a stylized model, we illustrate this point in Appendix A1 (see Result 1). Most of the literature has focused entirely on the first effect, whereas the second (countervailing) channel has largely been ignored in the context of government guarantees. We would expect higher risk-taking only if the market discipline effect dominates the charter value effect.

However, the presence of government guarantees may not only affect the risk-taking of 
protected banks, but also - through competition - that of the protected banks' competitors. In fact, public guarantees reduce the margins and charter values of competitor banks due to fiercer competition from banks that are able to refinance at subsidized rates (Hakenes and Schnabel, 2009). This pushes competitors towards higher risk-taking. Therefore, we would expect public guarantees to unambiguously increase the risk-taking of the competitor banks. This is the content of Result 2 in Appendix A1.

The empirical literature has again focused almost entirely on the effect of government guarantees on the protected banks' risk-taking. Most empirical papers come to the conclusion that banks increase their risk-taking in the presence of public guarantees. For example, Hovakimian and Kane (2000) have found evidence for higher risk-taking of banks in the presence of deposit insurance. In contrast, Gropp and Vesala (2004) find that explicit deposit insurance reduces banks' risk-taking. They argue that explicit deposit insurance may mitigate moral hazard because it may serve as a commitment device to limit the safety net. Hence, their evidence points towards a risk-increasing effect of implicit deposit insurance. Relatedly, large banks - which may be perceived to be "too big to fail" have been shown to follow riskier strategies than smaller banks (Boyd and Runkle 1993, Boyd and Gertler 1994, Schnabel 2004, 2009). The findings on the relationship between bank size and failure probabilities are mixed, but the more recent papers point towards higher failure probabilities at larger banks (Boyd and Runkle 1993, De Nicoló 2001, De Nicoló et al. 2004). In contrast, there is no conclusive evidence that public banks follow riskier strategies than private banks (De Nicolò and Loukoianova, 2007).

The effect of public bail-out guarantees on competitor banks has to our knowledge not yet been analyzed. The only related findings are by De Nicoló (2001) and De Nicoló and Loukoianova (2007) who find that banks in countries with a higher market share 
or concentration of government banks exhibit higher insolvency risk. This would be consistent with the theoretical predictions in Hakenes and Schnabel (2009).

The results on the overall effect of public bail-out guarantees on systemic stability are mixed. Demirgüç-Kunt and Detragiache (2002) present evidence for a negative effect of deposit insurance on banking stability, pointing towards a destabilizing effect of guarantees. Similarly, some papers find a negative relationship between bank stability and government ownership (Caprio and Martinez 2000) or bank concentration (De Nicoló et al. 2004). However, there also exist papers that are consistent with no or even a stabilizing effect of government guarantees. Barth et al. (2004) show that government ownership has no robust impact on bank fragility, once one controls for banking regulation and supervisory practices. Beck et al. (2006) find that systemic banking crises are less likely in countries with more concentrated banking sectors. These papers are difficult to reconcile with the evidence pointing towards a risk increase at protected banks. In contrast, they are compatible with the idea that the charter value effect dominates for protected banks.

Our paper will try to shed new light on these issues. Our main focus will be on the hypothesis that the protection of banks should result in higher risk-taking at the competitor banks, controlling for the bail-out probability of each individual bank. In addition, we will analyze whether bail-out guarantees increase or decrease the risk-taking of protected banks. One major challenge will be to construct a measure of banks' (explicit and implicit) bail-out guarantees. 


\section{Empirical analysis}

\subsection{Empirical model}

In the empirical analysis, we explain banks' risk-taking as a function of bank-specific and country-specific characteristics. The empirical specification is based on the theoretical literature on the effects of bail-out guarantees on bank risk-taking. Since the anticipation of a bail-out affects monitoring incentives, risk premia, and charter values (see Cordella and Yeyati, 2003, and Hakenes and Schnabel, 2009), risk-taking is expected to depend on the degree of protection of the bank itself. In addition, Hakenes and Schnabel (2009) have argued for a competitive effects of public guarantees, motivating the inclusion of a measure of the protection of the bank's competitors. Both effects are illustrated in the stylized theoretical model in Appendix A1.

To avoid contaminating effects, we control for other important determinants of bank risktaking suggested by the theoretical and empirical literature, such as size (as a measure of diversification, see for example Demsetz and Strahan, 1997), the intensity of bank competition (Keeley, 1990, Allen and Gale, 2004), deposit insurance (Merton, 1977, Kane, 1989), the procyclicality of risk-taking (Borio et. al, 2001), and transparency (Rosengren, 1999, Hyytinen and Takalo, 2002).

Hence, we model the risk-taking of bank $i$ in country $j$ as a function of the bank's own bailout probability, $p_{i j}$, a measure of the distortion of competition caused by the protection of competitor banks (which we name the market share of insured competitor banks, $M S I_{-i, j}$ ), as well as some control variables, $X_{i j}$ :

$$
\operatorname{Risk}_{i j}=\alpha_{0}+\alpha_{1} \cdot p_{i j}+\alpha_{2} \cdot M S I_{-i, j}+\alpha_{3} \cdot X_{i j}+\epsilon_{i j}
$$


The construction of all variables is explained in detail below. Our main hypothesis is that MSI increases banks' risk-taking. Under that hypothesis, we would expect $\alpha_{2}$ to be positive. Another coefficient of interest is that of the bank's own bail-out probability. If the market discipline effect dominates the charter value effect, $\alpha_{1}$ is expected to be positive; in the opposite case, it would be negative.

\subsection{Data}

Our major data source is Bureau van Dijk/IFCA's BankScope database which contains balance sheet and other bank-specific information for a large number of banks from a large variety of countries. Our analysis is based on the cross-section of banks from all OECD countries included in the BankScope database in the year 2003. ${ }^{1}$ We use the banks' unconsolidated statements if available. Hence, domestic and foreign subsidiaries are included as separate entities. Regarding bank specialization, we include commercial banks, cooperative banks, savings banks, real estate and mortgage banks, medium- and long-term credit banks, as well as specialized governmental credit institutions. Other, more specialized institutions, like investment banks and non-banking credit institutions, are not included in our data set. The remaining data set includes more than 5,000 banks from thirty countries. ${ }^{2}$ In the following, we will describe the construction of our major variables of interest, as well as other control variables, and present descriptive statistics of the data used in the analysis.

\footnotetext{
${ }^{1}$ Using a panel data set may increase efficiency, but does not help us in identification, because the time variation of the extent of public guarantees is very small.

${ }^{2}$ Further details on the preparation of the data set are contained in Appendix A2.
} 


\subsection{Public guarantees}

The most difficult and most important data issue is the measurement of public guarantees. The goal is to construct a bank-specific bail-out probability, which we call $p_{i j} .{ }^{3}$ This bail-out probability enters directly to measure the effect of a public guarantee on the protected bank's risk-taking. Moreover, we want to construct a variable that measures the competitive distortion due to the protection of competitor banks. This measure, which we call the market share of insured competitor banks, is constructed (from the viewpoint of a particular bank, say $k$ ) as

$$
M S I_{-k, j}=\sum_{i \neq k}^{N_{j}} p_{i j} \frac{a_{i j}}{A_{j}},
$$

where $N_{j}$ is the number of banks in country $j, a_{i j}$ are the total assets of bank $i$ in country $j$, and $A_{j}=\sum_{i}^{N_{j}} a_{i j}$ are total bank assets in country $j$. If all banks had either a bail-out probability of zero or one, this variable would simply give us the market share of insured competitor banks (hence the name of the variable). Note that the variable MSI does not only vary across countries, but also across banks within countries, because the bank itself is always excluded from the calculation.

Through a simple transformation, MSI can be written as the product of the competitors' average bail-out probability and the competitors' total market share,

$$
M S I_{-k, j}=p_{-k, j} \frac{A_{-k, j}}{A_{j}}
$$

where $p_{-k, j}=\sum_{i \neq k}^{N_{j}} p_{i j} \frac{a_{i j}}{A_{-k, j}}$ is the competitors' average bail-out probability, weighted by market shares, and $A_{-k, j}=A_{j}-a_{k j}$ are the competitors' total assets in country $j$.

\footnotetext{
${ }^{3}$ Note that this probability is the conditional probability of a bail-out, given that the bank runs into problems.
} 
Hence, the higher the protected competitors' average bail-out probability and the higher the competitors' total market share, the higher will be the competitive distortion.

The main challenge is the estimation of bail-out probabilities. We use two methodologies to construct these bail-out probabilities. Depending on the procedure used, we call the resulting variables $p 1$ or $p 2$, and $M S I 1$ or $M S I 2$, respectively.

Construction of $M S I$ on the basis of support ratings (MSI1) The most straightforward procedure for calculating the market share of insured competitor banks is based on the Support Ratings provided by the rating agency Fitch/IBCA. These ratings reflect the rating agency's expectations of the likelihood of external support to individual banks (see Table 1 and Gropp et al. 2006 for a detailed description of such ratings). We assign bail-out probabilities to Fitch/IBCA's support ratings, based on the description of the support ratings as given by Table $1 .^{4}$

Publicly owned banks are assigned a bail-out probability of one. In addition, domestic subsidiaries are assigned the bail-out probability of their mother company, whereas foreign subsidiaries are treated as independent entities. Finally, all remaining private banks that are not rated are assigned a bail-out probability of zero; the idea is that banks that are not important enough to be rated are not important enough to be bailed out if they fail. The bail-out probability calculated on the basis of this assignment is named $p 1$, the corresponding market share of insured competitor banks MSI1. The assignment of bail-out probabilities is, of course, somewhat arbitrary. Therefore, we present several alternative ways to estimate bail-out probabilities from the data.

\footnotetext{
${ }^{4} \mathrm{~A}$ similar procedure appeared to work well in Gropp et al. (2006).
} 
Table 1: Description of support ratings by Fitch/IBCA and assignment of bail-out probabilities $p 1$ for the construction of $M S I 1$

\begin{tabular}{|c|c|c|}
\hline Support rating & Description by Fitch & $\begin{array}{l}\text { Assigned bail } \\
\text { out probability }\end{array}$ \\
\hline 1 & $\begin{array}{l}\text { A bank for which there is an extremely high probability of external support. The potential provider of support is } \\
\text { very highly rated in its own right and has a very high propensity to support the bank in question. This probability } \\
\text { of support indicates a minimum Long-term rating floor of 'A-'. }\end{array}$ & $x_{2}$ \\
\hline 2 & $\begin{array}{l}\text { A bank for which there is a high probability of external support. The potential provider of support is highly rated } \\
\text { in its own right and has a high propensity to provide support to the bank in question. This probability of support } \\
\text { indicates a minimum Long-term rating floor of 'BBB-'. }\end{array}$ & 0.9 \\
\hline 3 & $\begin{array}{l}\text { A bank for which there is a moderate probability of support because of uncertainties about the ability or } \\
\text { propensity of the potential provider of support to do so. This probability of support indicates a minimum Long- } \\
\text { term rating floor of 'BB-'. }\end{array}$ & 0.5 \\
\hline 4 & $\begin{array}{l}\text { A bank for which there is a limited probability of support because of significant uncertainties about the ability or } \\
\text { propensity of any possible provider of support to do so. This probability of support indicates a minimum Long- } \\
\text { term rating floor of 'B'. }\end{array}$ & 0.25 \\
\hline
\end{tabular}

\section{Construction of $M S I$ on the basis of individual and issuer ratings (MSI2) In}

addition to the Support Ratings, Fitch/IBCA also provides a rating that measures the inherent strength of the bank, explicitly ignoring the likelihood of external support if the bank experiences difficulties. This rating is called the Individual Rating. Finally, the rating agency provides a standard Issuer Rating, which assesses the overall issuer risk, taking into account any external support. The second version of $M S I$ uses these two ratings to construct the bail-out probability $p 2$ and the market share MSI2. The main idea is to utilize the information contained in the deviations of Issuer Ratings from Individual Ratings to deduct the banks' bail-out probabilities. ${ }^{5}$

For this purpose, we first translate the two ratings into default probabilities. This is done on the basis of standard rating transition matrices for non-financial firms, from which we

\footnotetext{
${ }^{5}$ Consistent with our procedure, Rime (2006) shows that part of the difference between issuer and individual ratings can be explained by a bank's size, which he interprets as evidence for "too big to fail" expectations.
} 
can calculate the historical default rates (Table 2). ${ }^{6}$

Table 2: Historical one-year ahead default probabilities for non-financial firms (in percent), as used for construction of $M S I 2$

\begin{tabular}{cc}
\hline Rating Fitch/IBCA & Default probability \\
\hline AAA & 0.00 \\
AA+ & 0.00 \\
AA & 0.00 \\
AA- & 0.00 \\
A+ & 0.00 \\
A & 0.00 \\
A- & 0.14 \\
BBB+ & 0.33 \\
BBB & 0.15 \\
BBB- & 0.54 \\
BB+ & 1.06 \\
BB & 2.09 \\
BB- & 1.90 \\
B+ & 2.29 \\
B & 1.74 \\
B- & 1.96 \\
C-CCC & 27.20 \\
\hline
\end{tabular}

Notes: Data refer to the years 1994-2000. Source: Fitch/IBCA (2005), p. 7.

We then make use of the following relationship:

$$
t d_{i j}=d_{i j}\left(1-p_{i j}\right)
$$

where $t d_{i j}$ is the total default probability (taking into account bail-outs) of bank $i$ in country $j$, and $d_{i j}$ is the default probability in the absence of bail-outs. Hence, $t d_{i j}$ corresponds to the default probability as reflected in the issuer rating, whereas $d_{i j}$ corresponds to the individual rating. From this formula we can calculate the bail-out probability as

$$
p_{i j}=1-\frac{t d_{i j}}{d_{i j}}
$$

unless the default probability $d_{i j}$ is equal to zero (i. e., when the ratings are associated with a zero historical default frequency, cf. Table 2). We therefore proceed as follows:

\footnotetext{
${ }^{6}$ It is important not to use the default probabilities of financial firms, as these would themselves be affected by the safety net.
} 
1. If $d_{i j}>0$, we calculate the bail-out probability directly from the above formula. Note that $p_{i j}$ is equal to 1 if $t d_{i j}=0$ and $d_{i j}>0$.

2. If $d_{i j}=t d_{i j}=0$, we employ the information from the support ratings (using the same assignment as in Table 1) to determine bail-out probabilities.

3. As before, domestic subsidiaries are assigned the mother company's bail-out probability.

4. All publicly owned banks are assigned a bail-out probability of one.

5. Finally, all remaining private banks that are not rated are again assigned a bail-out probability of zero.

In section 6, we also present the results from a third approach that avoids assigning bail-out probabilities altogether.

\subsection{Risk measures}

As dependent variables we use the following broad set of variables found in the literature to capture different aspects of risk in banking: ${ }^{7}$ (i) Problem loans ratio, defined as problem loans over total assets (Shrieves and Dahl, 1992 and many others since then); (ii) Problem loans ratio 2004, which is the one period ahead value of the problem loans ratio to account for the backward-looking nature of problem loans; (iii) risk asset ratio, defined as risk assets (i. e. assets with non-negligible credit and market risk) over total assets (Furlong,

\footnotetext{
${ }^{7}$ All variables are calculated from the Bankscope data and have been winsorized at the 1st and 99th percentiles.
} 
1988); (iv) liquidity ratio, defined as liquid assets over short-term liabilities; (v) equity ratio, defined as book capital over total assets as a measure of leverage risk. ${ }^{8}$

All of these variables are calculated from balance-sheet data. In spite of the well-known shortcomings of balance sheet data, their use is preferable here because the use of market data would severely constrain our sample size. In particular, we would lose many of the smaller banks.

\subsection{Control variables}

We use a standard set of bank-specific and country-specific control variables: ${ }^{9}$

Total assets (in logarithmic form) are used to measure a bank's market power, returns to scale, and diversification benefits. The inclusion of this variable is particularly important because it allows us to distinguish between the risk effects of diversification and those of expected bail-outs. Moreover, in part of the regressions, we control for different types of business (such as commercial banks, savings banks, etc.) by inserting dummy variables for bank types.

At the country level, we use the Herfindahl index (the sum of squared market shares, according to banks' total assets) to measure the concentration in a country's banking sector. In theory, a higher concentration should increase intermediation margins and thereby decrease risk-taking (see, e. g., Keeley 1990). We also control for the generosity of the deposit insurance system, as measured by country-specific coverage limits (see Table

\footnotetext{
${ }^{8}$ We also tried the regulatory capital ratio, defined as regulatory capital divided by risk-weighted assets according to Basel I, as a risk measure. However, this variable proved to be insignificant in all of our regressions. We attribute this finding to the risk insensitivity of Basel I and the ample opportunities for regulatory arbitrage it provides. Indeed, this was the main motivation for introducing Basel II.

${ }^{9}$ See Table A1 in the Appendix for a detailed description of data sources.
} 
A1 in the Appendix for details). Demirgüç-Kunt and Detragiache (2002) find that deposit insurance increases the likelihood of banking crises, which suggests a risk-increasing effect of deposit insurance. In contrast, Gropp and Vesala (2004) argue that explicit deposit insurance reduces banks' risk-taking.

Risk-shifting should be more difficult if there are stricter information disclosure requirements. Therefore, we control for the transparency of the banking sector (see again Table A1 in the Appendix for details). Finally, we control for business cycle effects by including the deviation from trend of real GDP growth, and for financial development by including GDP per capita. In some regressions, we also include country fixed effects.

\subsection{Descriptive statistics}

Table 3 shows the descriptive statistics at the bank level. Note that the MSI variables vary not only across countries, but also across banks within a given country because the bank itself is excluded from the calculation of $M S I$. In our data set, the average bailout probability $p 1$ (corresponding to $M S I 1$ ) is 0.20 and the average $p 2$ (corresponding to $M S I 2)$ is 0.21 . These relatively low numbers reflect the fact that there are a large number of small banks with relatively low bail-out probabilities. The average MSI1 and $M S I 2$ are both equal to 0.61 , showing that the average protection of competitor banks is substantial.

Table 4 presents the descriptive statistics at the country level. Most importantly, the table displays the measures MSI1country and MSI2country for the thirty countries in our data set. ${ }^{10}$ These variables are based on MSI1 and MSI2; however, they include

\footnotetext{
${ }^{10}$ Note that the variables used in the regressions are $M S I 1$ and $M S I 2$, and not the variables calculated at the country level. The variable MSI1country and MSI2country are shown to demonstrate country differences in government protection.
} 
Table 3: Descriptive statistics at the bank level

See Appendix A2 and Table A1 for details on the compilation of the data set, and for data sources and definitions of all variables. Variables marked by * have been winsorized at the 1 and $99 \%$ level.

\begin{tabular}{lccccc}
\hline \hline Variable & $\mathbf{N}$ & Mean & Std. dev. & Minimum & Maximum \\
& & & & & \\
\hline \hline & & & & & \\
Problem loans ratio (in \%)* & 2314 & 2.82 & 3.02 & 0.00 & 13.58 \\
Problem loans ratio 2004 (in \%)* & 2004 & 2.76 & 3.08 & 0.00 & 14.84 \\
Risk assets ratio (in \%)* & 5400 & 75.45 & 19.79 & 7.69 & 99.23 \\
Liquidity ratio (in \%)* & 5352 & 34.46 & 43.76 & 0.80 & 322.73 \\
Equity ratio (in \%)* & 5393 & 9.27 & 9.27 & 1.12 & 65.82 \\
Bail-out probability (p1) & 5443 & 0.20 & 0.38 & 0.00 & 1.00 \\
MSI1 & 5443 & 0.61 & 0.18 & 0.00 & 0.87 \\
Bail-out probability (p2) & 5443 & 0.21 & 0.39 & 0.00 & 1.00 \\
MSI2 & 5443 & 0.61 & 0.19 & 0.00 & 0.87 \\
Total assets (in Thousands USD) & 5443 & $1.07 \mathrm{E}+07$ & $5.34 \mathrm{E}+07$ & $2.27 \mathrm{E}+03$ & $1.11 \mathrm{E}+09$ \\
Net interest margin* & 5293 & 0.027 & 0.013 & 0.001 & 0.085 \\
& & & & \\
\hline \hline
\end{tabular}

all banks in a given country, so that they are constant within countries. A high value of MSIcountry can derive from two sources: from a high share of publicly owned banks (Public share, see column 9 in Table 4), i. e., from explicit government guarantees, or from a high share of banks that are likely to be bailed out for other reasons (most importantly, large banks), i.e., from implicit government guarantees (corresponding to the difference between MSIcountry and Public share). In the United Kingdom, for example, almost two thirds of the banking sector are likely to be bailed out even though there are no public banks. In contrast, the high value of MSIcountry in Germany is to a large extent driven by the high share of publicly owned banks. The variation of MSIcountry is quite large across countries: The lowest value $(0 \%)$ is found in New Zealand, the highest in Finland (87\%); the latter value is largely driven by the dominant position of Nordea in Finland, consistent with Finland's high Herfindahl index (column 10). We also report the within-country standard deviation of MSI1country and MSI2country (columns 5 and 8 in Table 4). As expected, the within-country standard deviations of MSI1country and MSI2country vary strongly with the concentration of the banking system. For example, 
the U.S., Germany, and Italy, all countries with low concentration, exhibit low withincountry variation of both MSIcountry measures. In contrast, in Finland, Portugal, or Greece, all countries with concentrated banking systems, there is a much higher withincountry variation of MSIcountry. The within-country variation of MSIcountry is also determined by the homogeneity of bail-out probabilities within a country. An extreme example is New Zealand, where all banks have a bail-out probability of zero, which implies no within-country variation of MSIcountry.

Finally, in columns 4 and 7 of the table, we report the country ranks for MSIcountry 1 and MSIcountry2. While the ranks of countries are broadly similar across the two measures, there are important differences (e.g. Belgium, Greece, Hungary, Italy, South Korea), which justify reporting empirical results for both MSI1 and MSI2.

Table 4. Descriptive statistics at the country level

The columns MSI1 (country) and MSI2 (country) give the overall values for each country. The MSI variables used in the regressions differ from the aggregate variables in that they do not include the respective bank itself. See Appendix A2 and Table A1 for details on the compilation of the data set, and for data sources and definitions of all variables. See the text for the definitions of MSI1 and MSI2.

\begin{tabular}{|c|c|c|c|c|c|c|c|c|c|c|c|c|c|}
\hline Country & $\begin{array}{l}\text { Number } \\
\text { of banks }\end{array}$ & $\begin{array}{c}\text { MSI1 } \\
\text { (country) }\end{array}$ & $\begin{array}{c}\text { Country } \\
\text { rank }\end{array}$ & $\begin{array}{l}\text { MSI1 within- } \\
\text { country } \\
\text { standard } \\
\text { deviation }\end{array}$ & $\begin{array}{c}\text { MSI2 } \\
\text { (country) }\end{array}$ & $\begin{array}{l}\text { Country } \\
\text { rank }\end{array}$ & $\begin{array}{l}\text { MSI2 within- } \\
\text { country } \\
\text { standard } \\
\text { deviation }\end{array}$ & $\begin{array}{c}\text { Public } \\
\text { share }\end{array}$ & Herfindahl & $\begin{array}{l}\text { GDP per } \\
\text { capita }\end{array}$ & $\begin{array}{l}\text { Real GDP } \\
\text { growth }\end{array}$ & $\begin{array}{c}\text { Deposit } \\
\text { insurance }\end{array}$ & $\begin{array}{c}\text { Trans- } \\
\text { parency }\end{array}$ \\
\hline Australia & 44 & $81 \%$ & 6 & $4.7 \%$ & $80 \%$ & 4 & $4.7 \%$ & $9 \%$ & 13.7 & 21,204 & $4.2 \%$ & 0 & 12 \\
\hline Austria & 183 & $31 \%$ & 28 & $1.5 \%$ & $29 \%$ & 29 & $1.4 \%$ & $8 \%$ & 9.5 & 25,649 & $1.0 \%$ & 1 & 8 \\
\hline Belgium & 66 & $68 \%$ & 10 & $2.9 \%$ & $33 \%$ & 27 & $5.1 \%$ & $0 \%$ & 23.0 & 24,431 & $1.6 \%$ & 1 & 9 \\
\hline Canada & 43 & $78 \%$ & 7 & $4.8 \%$ & $78 \%$ & 5 & $4.8 \%$ & $1 \%$ & 13.9 & 23,511 & $3.3 \%$ & 2 & 11 \\
\hline Czech Republic & 22 & $59 \%$ & 13 & $6.7 \%$ & $63 \%$ & 11 & $6.6 \%$ & $6 \%$ & 16.5 & 7,379 & $1.6 \%$ & 1 & 9 \\
\hline Denmark & 95 & $58 \%$ & 14 & $4.2 \%$ & $58 \%$ & 14 & $4.2 \%$ & $0 \%$ & 22.6 & 32,421 & $0.5 \%$ & 2 & 7 \\
\hline Finland & 10 & $87 \%$ & 1 & $16.2 \%$ & $87 \%$ & 1 & $16.2 \%$ & $10 \%$ & 38.5 & 26,098 & $2.3 \%$ & 1 & 10 \\
\hline France & 287 & $65 \%$ & 11 & $1.4 \%$ & $64 \%$ & 9 & $1.5 \%$ & $4 \%$ & 6.9 & 24,472 & $1.2 \%$ & 2 & 8 \\
\hline Germany & 1486 & $77 \%$ & 8 & $0.4 \%$ & $83 \%$ & 3 & $0.4 \%$ & $51 \%$ & 2.6 & 24,531 & $0.1 \%$ & 3 & 11 \\
\hline Greece & 20 & $72 \%$ & 9 & $6.5 \%$ & $57 \%$ & 15 & $7.3 \%$ & $37 \%$ & 15.0 & 12,265 & $3.9 \%$ & 1 & 10 \\
\hline Hungary & 28 & $52 \%$ & 19 & $2.7 \%$ & $34 \%$ & 26 & $4.0 \%$ & $19 \%$ & 9.1 & 6,574 & $3.8 \%$ & 1 & 9 \\
\hline Iceland & 28 & $54 \%$ & 18 & $7.5 \%$ & $57 \%$ & 16 & $7.1 \%$ & $29 \%$ & 24.9 & 30,524 & $-1.3 \%$ & 1 & 8 \\
\hline Ireland & 38 & $40 \%$ & 25 & $2.9 \%$ & $40 \%$ & 22 & $2.9 \%$ & $4 \%$ & 13.9 & 31,228 & $6.1 \%$ & 1 & 11 \\
\hline Italy & 695 & $55 \%$ & 17 & $0.6 \%$ & $67 \%$ & 8 & $0.5 \%$ & $3 \%$ & 2.6 & 21,134 & $0.3 \%$ & 3 & 12 \\
\hline Japan & 628 & $57 \%$ & 16 & $0.5 \%$ & $44 \%$ & 20 & $0.6 \%$ & $12 \%$ & 3.2 & 30,674 & $0.1 \%$ & 2 & 11 \\
\hline Luxembourg & 87 & $38 \%$ & 27 & $1.4 \%$ & $38 \%$ & 25 & $1.4 \%$ & $24 \%$ & 4.4 & 50,579 & $3.6 \%$ & 1 & 11 \\
\hline Mexico & 39 & $52 \%$ & 20 & $3.1 \%$ & $41 \%$ & 21 & $3.7 \%$ & $23 \%$ & 10.8 & 6,313 & $0.7 \%$ & 3 & 12 \\
\hline Netherlands & 44 & $81 \%$ & 5 & $7.8 \%$ & $86 \%$ & 2 & $7.3 \%$ & $9 \%$ & 30.0 & 27,339 & $0.1 \%$ & 1 & 10 \\
\hline New Zealand & 9 & $0 \%$ & 30 & $0.0 \%$ & $0 \%$ & 30 & $0.0 \%$ & $0 \%$ & 17.7 & 15,556 & $4.4 \%$ & 0 & 12 \\
\hline Norway & 53 & $38 \%$ & 26 & $3.2 \%$ & $39 \%$ & 23 & $3.2 \%$ & $26 \%$ & 15.4 & 42,092 & $1.2 \%$ & 3 & 11 \\
\hline Poland & 37 & $52 \%$ & 21 & $3.8 \%$ & $57 \%$ & 17 & $3.8 \%$ & $25 \%$ & 9.3 & 5,130 & $1.4 \%$ & 1 & 11 \\
\hline Portugal & 23 & $46 \%$ & 24 & $6.1 \%$ & $52 \%$ & 18 & $6.0 \%$ & $27 \%$ & 16.3 & 12,382 & $0.8 \%$ & 1 & 10 \\
\hline Slovakia & 19 & $48 \%$ & 23 & $5.3 \%$ & $38 \%$ & 24 & $5.4 \%$ & $2 \%$ & 14.3 & 4,555 & $4.2 \%$ & 1 & 8 \\
\hline South Korea & 19 & $83 \%$ & 3 & $4.7 \%$ & $60 \%$ & 12 & $5.3 \%$ & $39 \%$ & 10.0 & 11,595 & $7.0 \%$ & 2 & 11 \\
\hline Spain & 144 & $57 \%$ & 15 & $1.9 \%$ & $64 \%$ & 10 & $1.8 \%$ & $0 \%$ & 6.5 & 16,546 & $2.7 \%$ & 1 & 11 \\
\hline Sweden & 113 & $84 \%$ & 2 & $2.8 \%$ & $74 \%$ & 6 & $2.8 \%$ & $8 \%$ & 11.5 & 27,360 & $2.0 \%$ & 1 & 10 \\
\hline Switzerland & 375 & $83 \%$ & 4 & $2.7 \%$ & $71 \%$ & 7 & $2.8 \%$ & $18 \%$ & 29.4 & 38,437 & $0.4 \%$ & 1 & 10 \\
\hline Turkey & 32 & $50 \%$ & 22 & $3.9 \%$ & $47 \%$ & 19 & $3.7 \%$ & $36 \%$ & 9.9 & 2,631 & $7.8 \%$ & 3 & 9 \\
\hline United Kingdom & 201 & $65 \%$ & 12 & $1.5 \%$ & $59 \%$ & 13 & $1.5 \%$ & $0 \%$ & 6.3 & 26,650 & $1.8 \%$ & 1 & 12 \\
\hline USA & 575 & $28 \%$ & 29 & $0.4 \%$ & $30 \%$ & 28 & $0.4 \%$ & $0 \%$ & 3.3 & 36,124 & $1.6 \%$ & 3 & 11 \\
\hline
\end{tabular}




\section{Estimation results}

Table 5 presents the regression results from our basic specification using $M S I 1$ and $p 1$. The columns refer to the different measures of banks' risk-taking. Table 6 adds fixed effects for bank types.

The regression results in Tables 5 and 6 convey that a higher market share of insured competitor banks significantly increases banks' risk-taking for all risk variables. The coefficients are also economically significant: For example, an increase in $M S I 1$ by 0.1 (for example, from $30 \%$ to $40 \%$ ) increases the share of problem loans in total assets by 0.56 percentage points according to Table 5 , which is substantial given a mean of 2.82 percent (see Table 3). The effect of the same increase of $M S I 1$ on the equity ratio would be a decrease of 1.1 percentage points, which is again quite large.

Another interesting result concerns the effect of a bank's own bail-out probability on risktaking. We find that the own bail-out probability is either insignificant, or that it has a significant risk-decreasing effect on banks' risk-taking. This contradicts the conventional wisdom according to which a higher probability of a bail-out increases banks' risk-taking. However, it is consistent with theory if the charter value effect dominates the market discipline effect.

The remaining coefficients are largely as expected. Larger banks (as measured by the log of total assets) tend to have a lower share of problem loans (probably due to a better diversification of risks), a higher share of risk assets (due to differences in business strategies), lower liquidity (again due to better diversification), and lower equity ratios. Banks in countries with a higher GDP per capita (indicating a higher sophistication of the financial system) display fewer problem loans, a higher share of risk assets, lower liquidity 


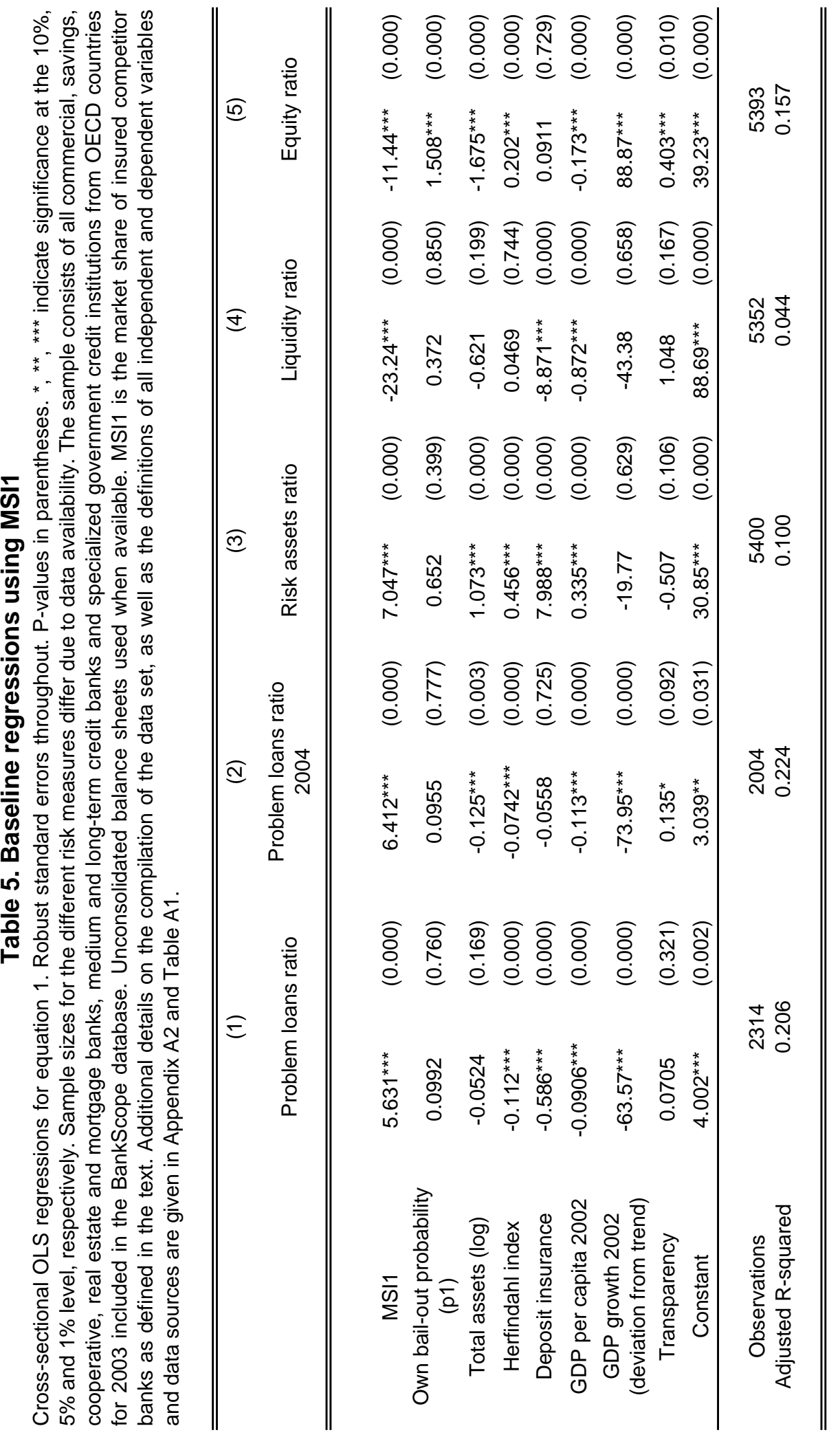




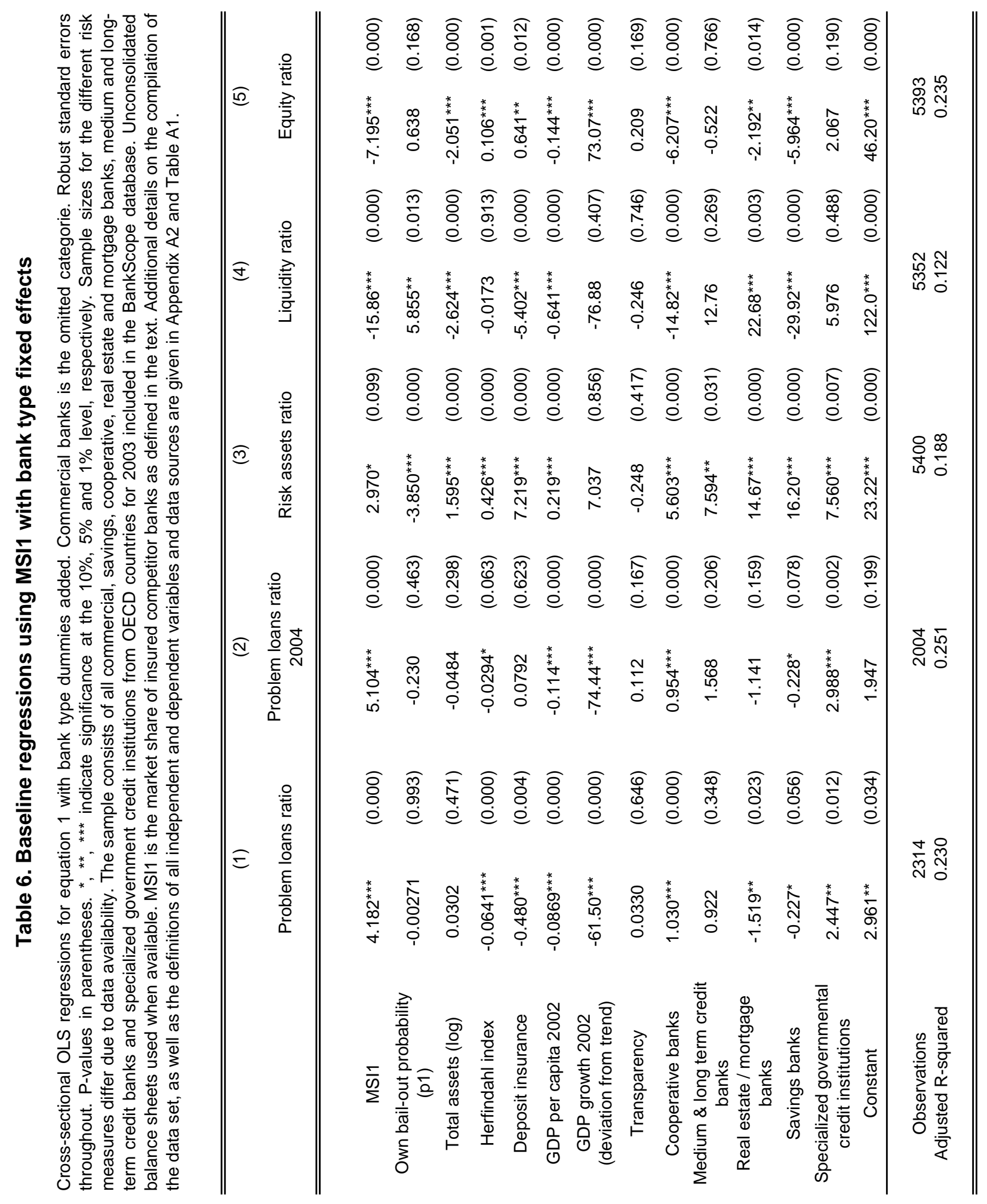


and a lower equity ratio. Business cycle upturns go along with fewer problem loans and higher equity ratios, but have no effects on liquidity.

The results on the effects of deposit insurance and concentration in the banking sector are somewhat mixed. A higher coverage of deposit insurance tends to increase risk-taking for some variables (such as the risk assets ratio and the liquidity ratio), while it reduces problem loans. A higher Herfindahl index decreases the problem loans ratio and increases the equity ratio; in contrast, it increases the risk assets ratio. Transparency is mostly insignificant. $^{11}$

We also find significant differences in the risk measures depending on bank types (Table 6). The omitted category is commercial banks. Relative to commercial banks, cooperative banks consistently take on more risk. Savings banks have less capital and liquidity compared to commercial banks, but also fewer problem loans. Mortgage banks hold more risk assets and have lower capital levels, but they also hold more liquidity and have fewer problem loans. And specialized governmental credit institutions have much more problem loans than commercial banks. Given that the protection through government guarantees and banks' types are not related one-to-one (e.g., savings banks are public in some countries, such as Germany, and private in others), the bank type dummies help us to distinguish the effects of bail-out guarantees from the effects of differences in business models and political lending (Sapienza, 2004).

Tables 7 and 8 present the same regressions, using MSI2 and $p 2$. The results are very similar to those presented in Tables 5 and 6. MSI2 significantly increases risk-taking in

\footnotetext{
${ }^{11}$ It has a significantly positive impact only on the problem loans ratio of 2004 and on the equity ratio. The first finding is probably driven by the fact that banks in transparent banking systems are obliged to disclose problem loans more quickly, rather than measuring an increase in risk.
} 


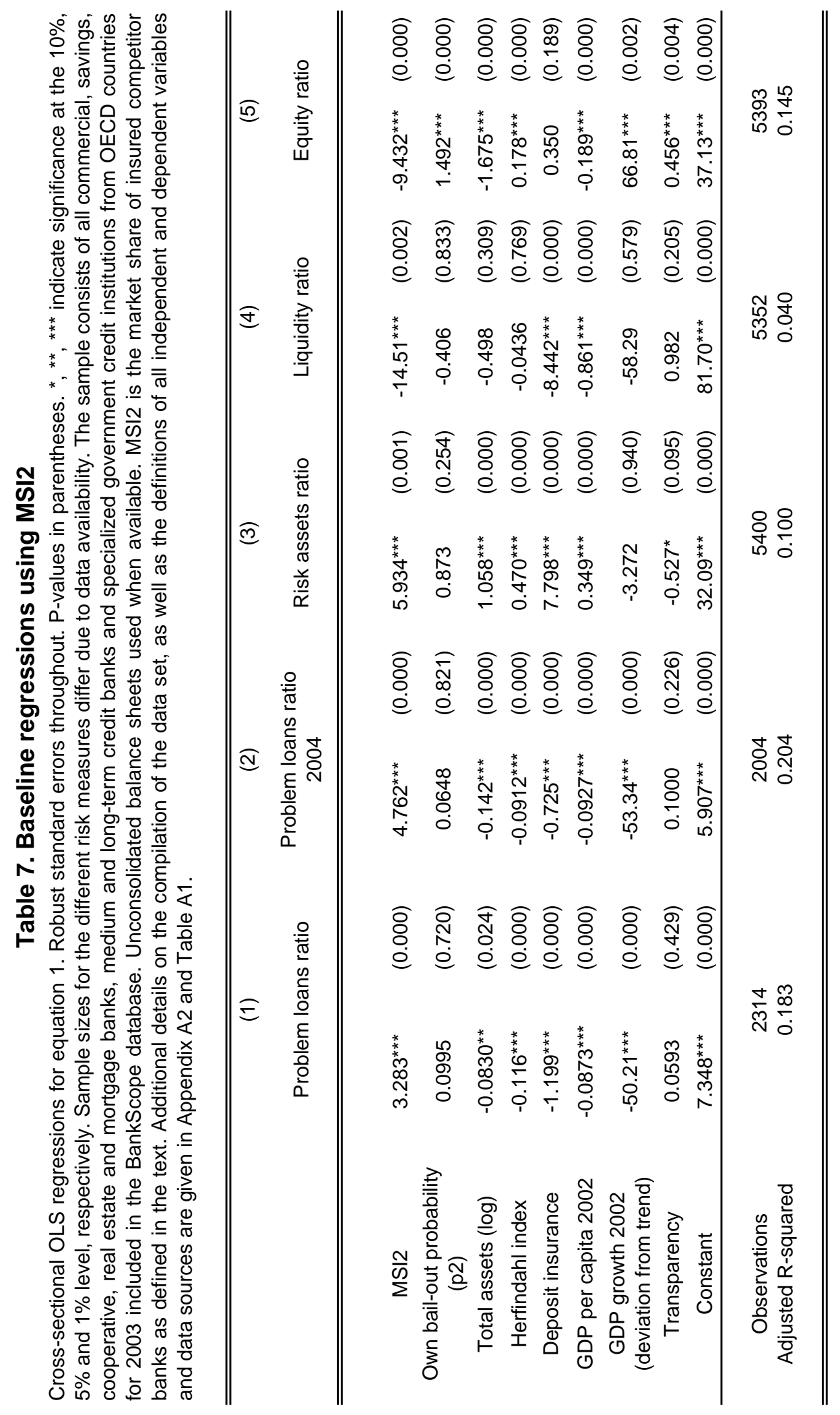




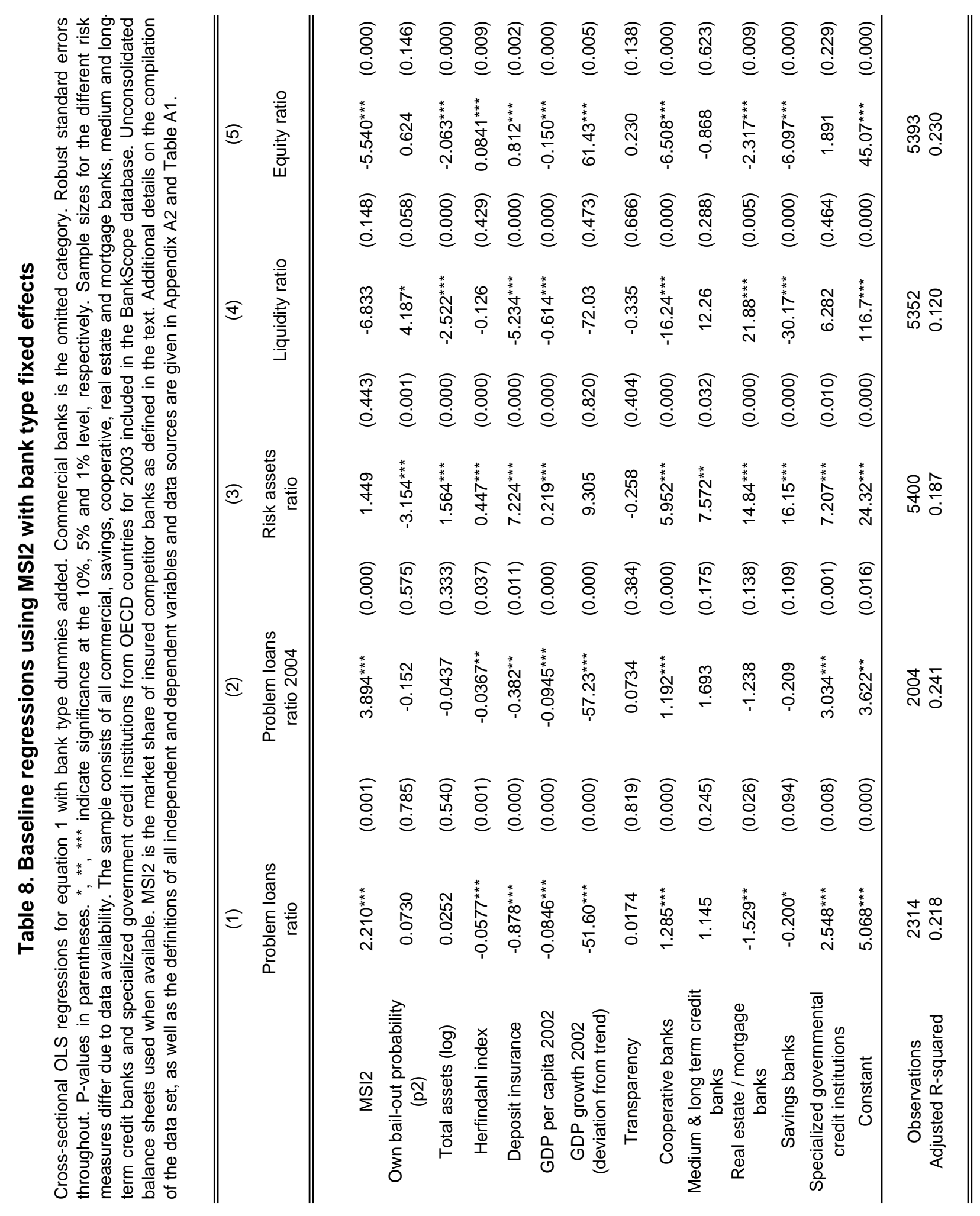


most regressions. Again, the own bail-out probability is either insignificant, or it has a risk-decreasing effect.

We checked the robustness of our results by adding country fixed effects to our regressions to make sure that the effects are not driven by unobserved country effects that are correlated with the MSI variables. The results of these regressions are shown in Table 9. We find that the precision of the estimates generally decreases, as expected. Nevertheless, MSI remains significantly positively related to higher risk in many cases, and retains the expected sign for all measures. The results referring to the own bail-out probability are also similar to those not including country dummies. These results are remarkable because these regressions "throw away" the between-country variation of $M S I$, implying that only the within-country variation is used to identify the coefficient of the MSI variable. Nevertheless, the main result appears to be robust. ${ }^{12}$

\section{Instrumental variable approach}

The baseline results are striking and consistent with the theoretical considerations. However, they are mute about the channels through which $M S I$ affects banks' risk-taking. In theory, the effect of bail-out guarantees on banks' risk-taking works through banks' interest margins (see Appendix A1). Due to the bail-out guarantee, insured banks expand, which compresses the margins of competitor banks. In reaction to increased competitive pressures, banks increase their risk-taking to maintain profitability. Higher risk-taking feeds back positively into margins. Therefore, risk-taking should depend negatively on the bank's margin, and margins should depend positively on risk-taking. This implies

\footnotetext{
${ }^{12}$ Note that these results are driven by countries with large within-country variation in $M S I$, such as Finland and the Netherlands (see Table 4).
} 


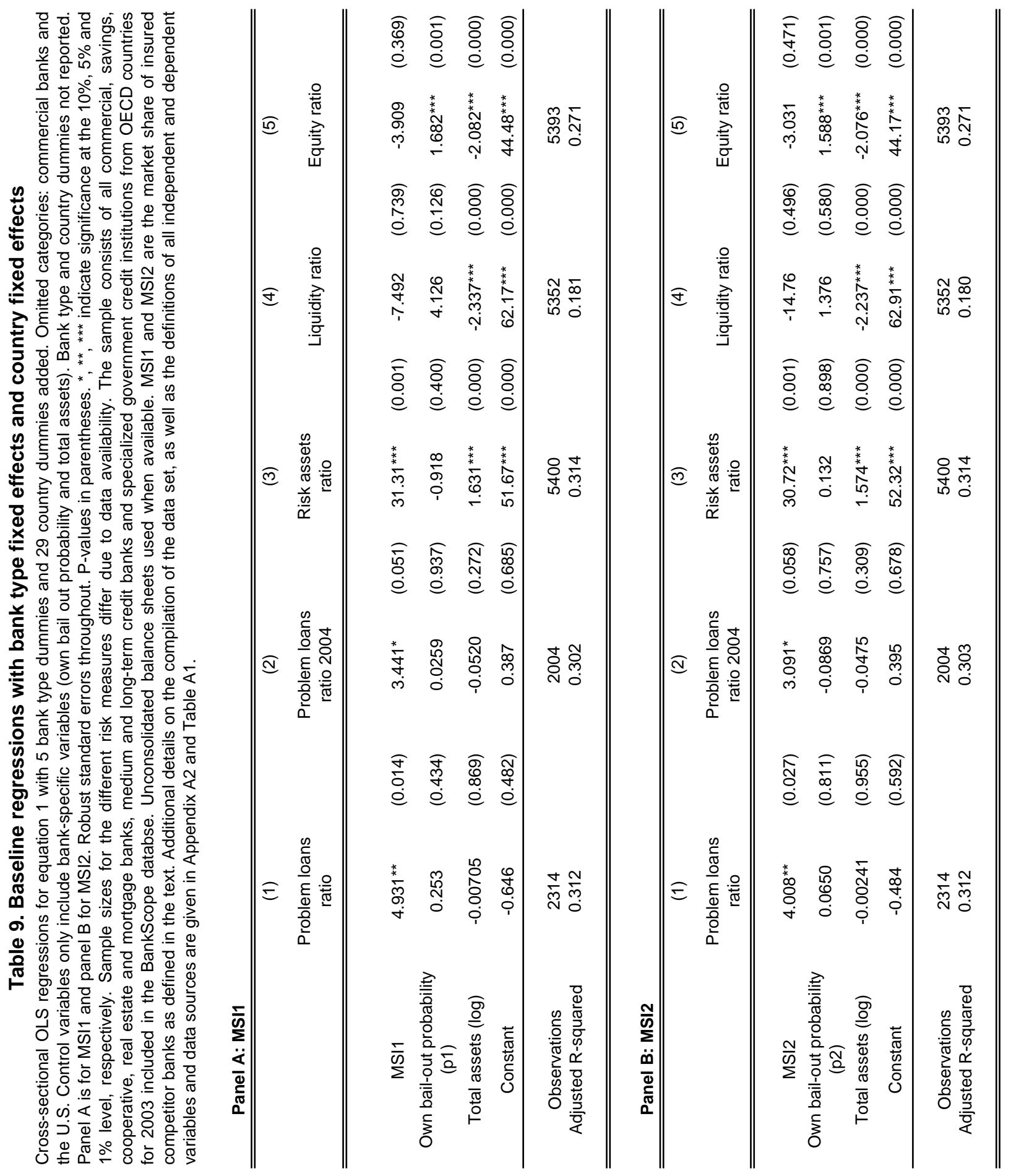


that one cannot simply include banks' margins as a control variable in the regressions. Instead, we consider the following simultaneous equations model:

$$
\begin{aligned}
\operatorname{Risk}_{i j} & =\alpha_{0}+\alpha_{1} \cdot \operatorname{Margin}_{i j}+\alpha_{2} \cdot X_{i j}+u_{i j}, \\
\operatorname{Margin}_{i j} & =\beta_{0}+\beta_{1} \cdot \text { Risk }_{i j}+\beta_{2} \cdot X_{i j}+\beta_{3} \cdot Z_{i j}+v_{i j} .
\end{aligned}
$$

Here, $X$ is a vector of exogenous variables that enter both equations. $Z$ is an instrument for interest margins, which is assumed to be orthogonal to the error term in the risk equation. We use $M S I$ as an instrument. The key identifying assumption is that $M S I$ affects banks' risk-taking only through the margin. This assumption is highly plausible. The only reason why the protection of competitors may affect risk-taking is competitive effects, which would show up in lower margins. Moreover, for the instrument to be relevant, MSI has to be correlated with the margin, which can be checked empirically. Using $M S I$ as an instrument, equation (6) is just identified. Hence, a two-stage least squares regression can be used to estimate the structural effect of a bank's margin on its risk-taking. However, in the absence of an instrument for Risk, we cannot identify equation (7). As the identification of the effect of risk on margins is not the primary concern of this paper, we make no attempt in this direction.

Table 10 displays the results from the instrumental variables regressions. As a measure of margins we use effective interest margins, i. e. the bank's net interest revenue divided by the volume of interest-bearing assets. The upper panel shows the results from the firststage regressions. We find that $M S I$ has a highly significant effect on banks' margins: The higher the market share of insured competitors, the lower are the banks' margins. ${ }^{13}$ The t-statistics range from -18.5 to -7.2 , suggesting that the instrument is not weak. The

\footnotetext{
${ }^{13}$ The differing estimation results in the first stages of the regressions derive only from the different sample sizes.
} 
Table 10. Instrumental variable model for MSI1

Instrumental variable model. Estimated using equations (6) and (7). Panel A reports the results for the first stage and panel B for the second stage. The dependent variable in the first stage is the net interest margin. The dependent variables in the second stage are the same risk measures as before. Robust standard errors throughout. P-values in parentheses. *, **, *** indicate significance at the $10 \%, 5 \%$ and $1 \%$ level, respectively. Sample sizes for the different risk measures differ due to data availability. The sample consists of all commercial, savings, cooperative, real estate and mortgage banks, medium and long-term credit banks and specialized government credit institutions from OECD countries for 2003 included in the BankScope databse. Unconsolidated balance sheets used when available. MSI1 is the market share of insured competitor banks as defined in the text. Additional details on the compilation of the data set, as well as the definitions of all independent and dependent variables and data sources are given in Appendix A2 and Table A1.

(1)

Problem loans ratio
(2)

Problem loans ratio 2004
(4)

\begin{tabular}{|c|c|c|c|c|c|c|c|c|c|c|}
\hline \multicolumn{11}{|c|}{ Panel A: First stage. Dependent variable: Net interest margin } \\
\hline \multirow{2}{*}{$\begin{array}{l}\text { MSI1 } \\
\text { Own bail-out probability } \\
(\mathrm{p} 1)\end{array}$} & \multirow{2}{*}{$\begin{array}{l}-0.0342^{\star \star \star} \\
0.000582\end{array}$} & $(0.000)$ & $-0.0329 * * *$ & $(0.000)$ & $-0.0192^{* * *}$ & $(0.000)$ & $-0.0193^{\star \star \star}$ & $(0.000)$ & $-0.0192^{* \star *}$ & $(0.000)$ \\
\hline & & $(0.647)$ & 0.000179 & $(0.886)$ & -0.000198 & $(0.654)$ & -0.000207 & $(0.641)$ & -0.000178 & $(0.687)$ \\
\hline Total assets (log) & $-0.00135^{\star \star \star}$ & $(0.000)$ & $-0.00131^{\star \star *}$ & $(0.000)$ & $-0.00200^{* * *}$ & $(0.000)$ & $-0.00200^{* * *}$ & $(0.000)$ & $-0.00200^{* * *}$ & $(0.000)$ \\
\hline Herfindahl index & $0.000398^{\star \star \star}$ & $(0.000)$ & $0.000394^{* * *}$ & $(0.000)$ & $0.000261^{* * *}$ & $(0.000)$ & $0.000256^{\star \star *}$ & $(0.000)$ & $0.000258^{\star \star \star}$ & $(0.000)$ \\
\hline Deposit insurance & $0.00690^{\star \star *}$ & $(0.000)$ & $0.00712^{\star \star \star}$ & $(0.000)$ & $0.00657^{* \star *}$ & $(0.000)$ & 0.00650 *** & $(0.000)$ & $0.00657^{* \star *}$ & $(0.000)$ \\
\hline GDP per capita 2002 & $-0.000423^{* * *}$ & $(0.000)$ & $-0.000385^{\star * *}$ & $(0.000)$ & $-0.000433^{* * *}$ & $(0.000)$ & $-0.000431^{\text {*** }}$ & $(0.000)$ & $-0.000432^{* * *}$ & $(0.000)$ \\
\hline $\begin{array}{l}\text { GDP growth } 2002 \\
\text { (deviation from trend) }\end{array}$ & $0.112^{*}$ & $(0.067)$ & 0.0831 & $(0.189)$ & $0.132^{* \star *}$ & $(0.000)$ & $0.128^{\star \star *}$ & $(0.000)$ & $0.132^{* \star *}$ & $(0.000)$ \\
\hline Transparency & $-0.00173^{* * *}$ & $(0.000)$ & $-0.00203^{\star * *}$ & $(0.000)$ & $-0.00100^{* * *}$ & $(0.000)$ & $-0.00103^{* * *}$ & $(0.000)$ & $-0.00100^{* * *}$ & $(0.000)$ \\
\hline Constant & $0.0776^{* * *}$ & $(0.000)$ & $0.0778^{\star \star \star}$ & $(0.000)$ & $0.0735^{\star \star \star}$ & $(0.000)$ & $0.0739^{\star \star \star}$ & $(0.000)$ & $0.0734^{\star * \star}$ & $(0.000)$ \\
\hline $\begin{array}{c}\text { Observations } \\
\text { Adjusted R-squared }\end{array}$ & \multicolumn{2}{|c|}{2298} & 1974 & 0.341 & \multicolumn{2}{|c|}{0.256} & \multicolumn{2}{|c|}{5254} & \multicolumn{2}{|c|}{0.256} \\
\hline Panel B: Second stage & \multicolumn{2}{|c|}{ (1) } & \multicolumn{2}{|l|}{ (2) } & \multicolumn{2}{|c|}{ (3) } & \multicolumn{2}{|c|}{ (4) } & \multicolumn{2}{|l|}{ (6) } \\
\hline Net interest margin & $-159.8^{\star * *}$ & $(0.000)$ & $-193.6^{\star \star \star}$ & $(0.000)$ & $-355.5^{\star \star *}$ & $(0.000)$ & $1167.0^{\star \star \star}$ & $(0.000)$ & $592.8^{\star \star *}$ & $(0.000)$ \\
\hline $\begin{array}{l}\text { Own bail-out probability } \\
\qquad(\mathrm{p} 1)\end{array}$ & 0.230 & $(0.568)$ & 0.220 & $(0.616)$ & 0.709 & $(0.398)$ & 0.428 & $(0.843)$ & $1.404^{* \star *}$ & $(0.001)$ \\
\hline Total assets (log) & $-0.261^{\star \star \star}$ & $(0.000)$ & $-0.382^{\star \star \star}$ & $(0.000)$ & 0.328 & $(0.162)$ & $1.622^{\star *}$ & $(0.015)$ & -0.459 *** & $(0.000)$ \\
\hline Herfindahl index & $-0.0490^{\star \star \star}$ & $(0.001)$ & -0.000880 & $(0.959)$ & $0.573^{\star \star *}$ & $(0.000)$ & $-0.349 * *$ & $(0.015)$ & 0.0427 & $(0.165)$ \\
\hline Deposit insurance & 0.396 & $(0.184)$ & $1.211^{* * *}$ & $(0.000)$ & $10.34^{* * *}$ & $(0.000)$ & $-16.43^{* * *}$ & $(0.000)$ & $-3.437^{\star * \star}$ & $(0.000)$ \\
\hline GDP per capita 2002 & $-0.160^{\star \star *}$ & $(0.000)$ & $-0.187^{\star * *}$ & $(0.000)$ & $0.175^{\star \star *}$ & $(0.001)$ & $-0.342^{\star \star \star}$ & $(0.005)$ & $0.0931^{\star \star *}$ & $(0.000)$ \\
\hline $\begin{array}{c}\text { GDP growth } 2002 \\
\text { (deviation from trend) }\end{array}$ & $-47.34^{* \star *}$ & $(0.001)$ & $-60.38^{\star * *}$ & $(0.000)$ & 13.44 & $(0.783)$ & -128.2 & $(0.261)$ & 25.71 & $(0.293)$ \\
\hline Transparency & -0.170 & $(0.156)$ & -0.226 & $(0.118)$ & $-0.809^{\star \star}$ & $(0.031)$ & $2.091^{* *}$ & $(0.025)$ & $0.868^{\star \star *}$ & $(0.000)$ \\
\hline Constant & $16.35^{\star \star \star}$ & $(0.000)$ & $18.05^{\star \star \star}$ & $(0.000)$ & $56.80^{\star \star *}$ & $(0.000)$ & 5.660 & $(0.772)$ & -4.341 & $(0.293)$ \\
\hline $\begin{array}{c}\text { Observations } \\
\text { F-statistic (overall } \\
\text { significance) }\end{array}$ & 225 & & 1974 & & 529 & & 525 & & 5286 & \\
\hline
\end{tabular}


effects are also quite large economically: Depending on the specification, an increase in MSI by 0.1 decreases the interest margin by between 0.19 and 0.34 percentage points (the mean of the interest margin is 2.7 percent, see Table 3 ).

The lower panel shows the second-stage regressions. We find that higher margins give rise to less risk-taking. Again, all effects are highly significant. These results strongly support the prediction of our model that the effect of MSI on banks' risk-taking runs through the banks' margins. ${ }^{14}$

\section{A flexible specification of bail-out probabilities}

As a further robustness check, we estimated a less parametric specification that avoids assigning bail-out probabilities altogether. In particular, the risk variables are regressed on the market shares (in terms of assets) of competitor banks from the different rating categories and on dummy variables indicating that a bank belongs to a certain rating category (plus the same control variables as above).

As shown in Appendix A3, the coefficient of the market share of the most highly protected bank group can be interpreted as the marginal effect of an increase in $M S I$ if one is willing to assume that this bank group is bailed out with probability one. ${ }^{15}$ Public banks and banks with the highest support rating are treated as one rating category (as before). The banks from the lowest rating category (including the non-rated banks) are the omitted

\footnotetext{
${ }^{14}$ We also ran regressions adding dummy variables for bank types (see Table A2 in the Appendix). These results are similar to those in Table 10. Only in one regression the interest margin becomes marginally insignificant. We also reran all regressions using MSI2 instead of MSI1. The results are virtually unchanged compared to Tables 10 and A2.

${ }^{15}$ If the bail-out probability were lower, the coefficient could be interpreted as the minimum effect that an increase in $M S I$ would have.
} 
category. The regressions do not include dummy variables for bank types. The regressions including bank type dummies are found in Table A3 in the Appendix.

The results from these regressions further support our main result. The parameter of interest can be found in the first line of Table 11. We find that the coefficient of the market share of competitor banks that are most likely to be bailed out (public banks or banks with a support rating of 1) has the expected sign for all measures of risk and is significant at the $1 \%$ level in three of the five regressions. An increase in the market share of these banks increases a competitor bank's risk-taking. The coefficients are somewhat smaller than before. Remember, however, that the true effect may well be larger if the bail-out probability of the most highly protected banks is lower than one.

\section{Public vs. private bank ownership}

As a last step, we check whether there is any distinction between the effects of implicit and explicit government guarantees. We therefore reran the main specification from Table 5, allowing for differential effects of explicit and implicit government guarantees. For this purpose, we decompose $M S I$ into two variables capturing the market shares of private or public insured competitors banks, respectively (named MSI private and MSI public). In addition, we allow for differential effects of own bail-out probabilities for private and public banks. The results are reported in Table 12 .

We find that the protection of both public and private banks has an effect on the risktaking of competitor banks. The effect of an increase in the market share of public competitor banks is somewhat larger (in absolute value) than that of an increase in the market share of privately owned insured competitor banks. The difference is significant 


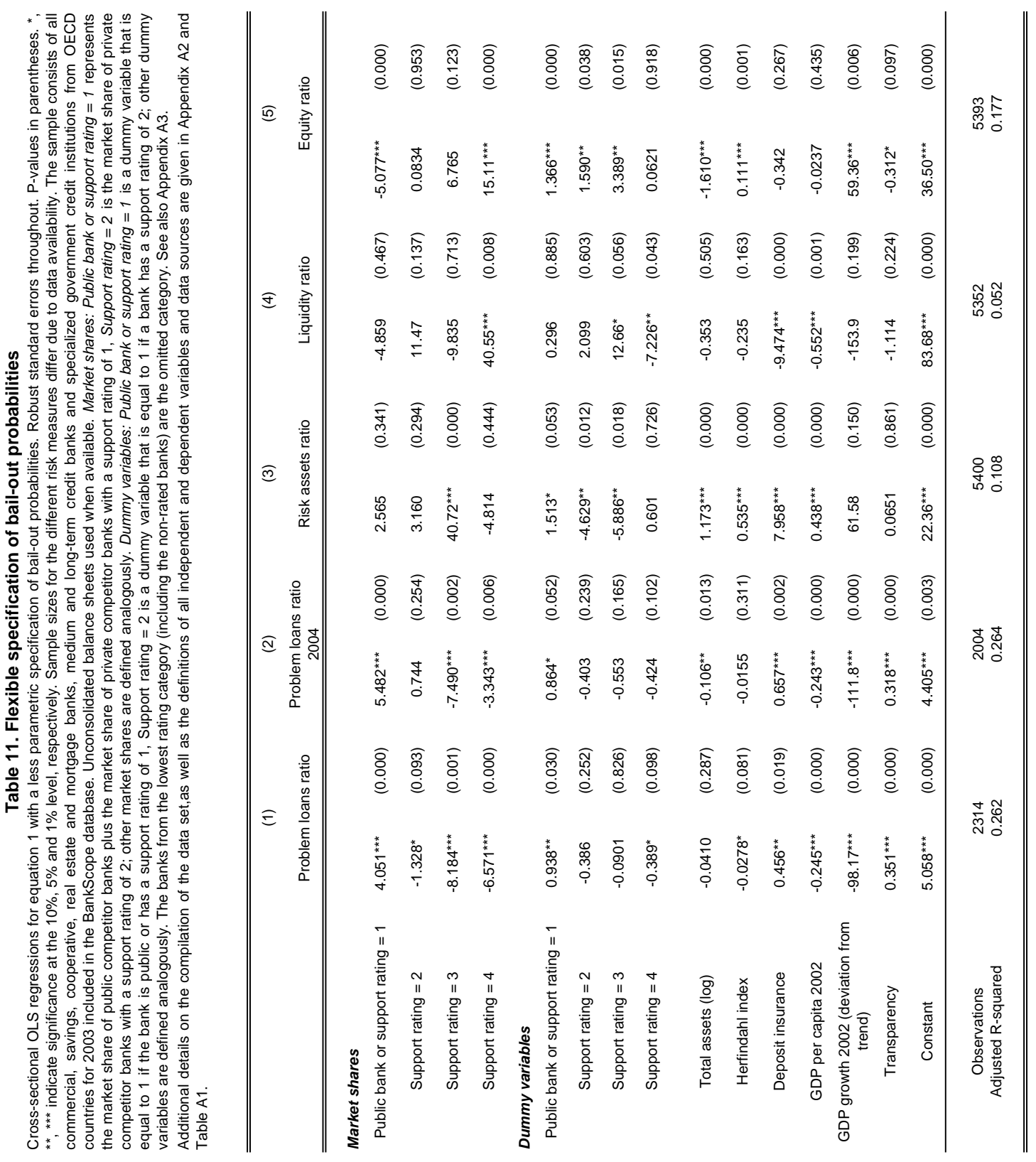


for three out of five risk measures (t-tests are reported at the bottom of the table). Nevertheless, the results suggest that both the market share of publicly owned competitor banks and the market share of implicitly insured competitor banks matter for the risktaking of competitors. Regarding the own bail-out probability, we find that public banks tend to have significantly more problem loans and risk assets, but also more equity. ${ }^{16}$ For private banks, a bank's own bail-out probability has a risk-decreasing effect for all risk variables (significant at least at the 5 percent level). In fact, the own bail-out probability increases risk more for public than for private banks for all risk measures, and this difference is always significant (at the 1 percent level). For private banks, the charter value effect seems to dominate the market discipline effect, while the converse is true for public banks. One possible explanation for these results is that public banks are less concerned about protecting their charter values than private banks. The lack of market discipline then explains the high risk-taking observed at public banks. Overall, the competitive effects of implicit government guarantees and of outright public ownership on risk-taking seem to be of similar economic magnitude, while the effect of government guarantees on the bank itself is different for outright public ownership and for implicit guarantees for private banks.

We then repeated the regressions from Table 11 using the full set of dummy variables and market shares, separating public and private banks (see Table 13). ${ }^{17}$ In this specification, the market share of publicly owned competitor banks has a large effect on risk-taking, which is always significant at the 1 percent level. The market share of private banks with a support rating of 1 also has a significant risk-increasing effect on the variables

\footnotetext{
${ }^{16}$ Note that the interaction term Own bail-out probability public is equivalent to a dummy variable for public banks, as the bail-out probability is always 1 for these banks.

${ }^{17}$ Table A4 in the Appendix contains the same regressions with bank type fixed effects. The results are very similar to those in Table 13.
} 


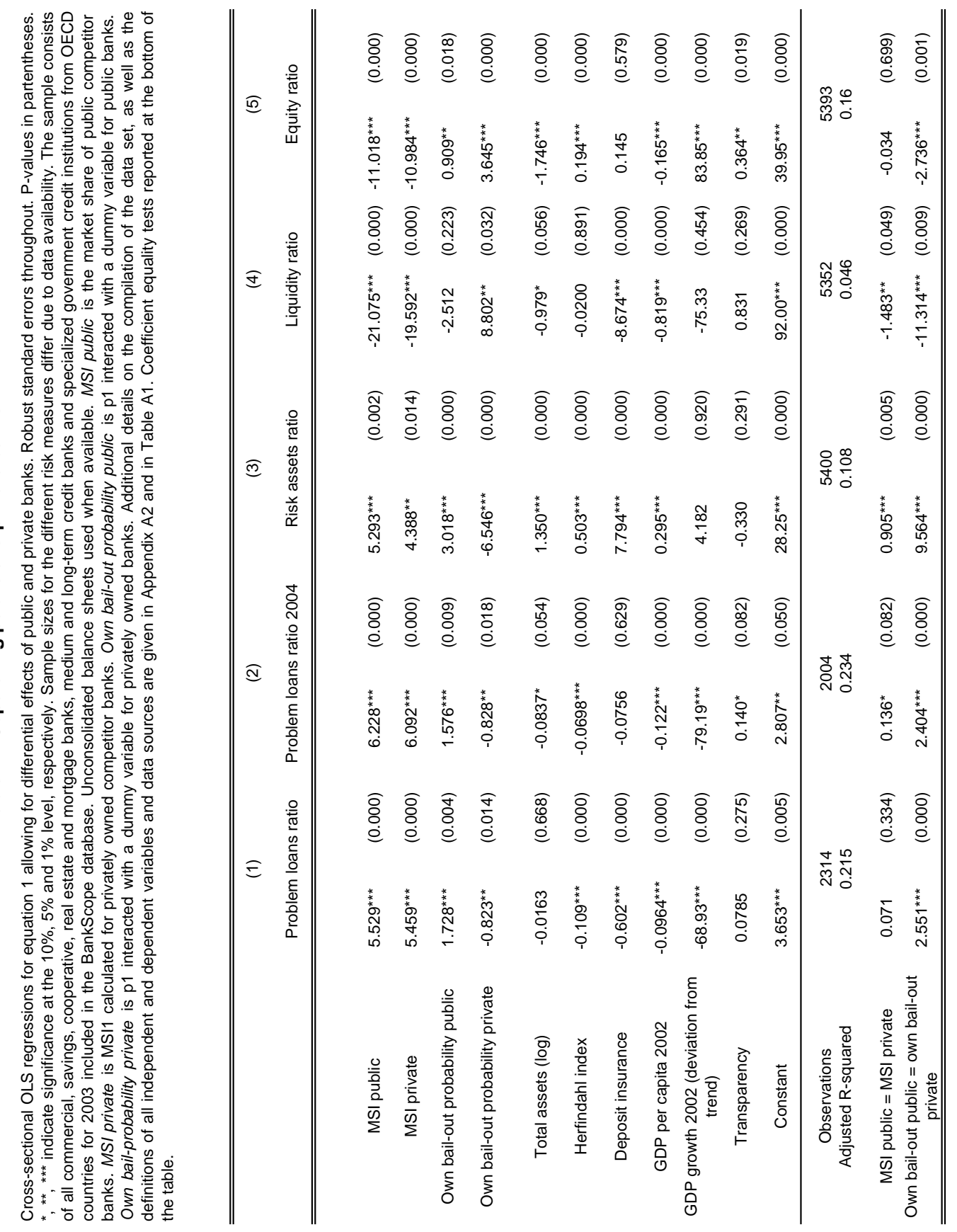


measuring loan quality (current problems loans and problem loans one year ahead), but not on the other variables. The difference between the effect of the market share of public competitor banks and the market share of private competitor banks with a support rating of 1 is relatively large and significant for four out of five risk measures. The effect of a bank's own bail-out probability is as in the previous specification. We find that public banks have higher problem loans and hold a higher share of risk assets than banks from the lowest rating category, indicating higher risk-taking at these banks. The results go in the opposite direction for highly rated private banks (sometimes significantly). ${ }^{18}$

Overall, the results of this section suggest that ownership matters, especially for the effect of the own bail-out probability. For public banks, the market discipline effect of guarantees tends to dominate the charter value effect, while for banks with a high implicit probability of being bailed out, the overall effect of implicit guarantees may even be a decrease in protected banks' risk-taking.

\section{Conclusion}

This paper analyzes the effect of public bail-out guarantees on the risk-taking of banks outside the safety net. To this end, we construct a variable measuring banks' implicit and explicit bail-out probabilities by using rating information that reflects the bail-out expectations of market participants. We then construct the variable MSI (market share of insured competitor banks), which is designed to capture the degree of competitive distortions in the banking sectors of different OECD countries due to implicit and explicit government guarantees. We test whether this variable increases banks' risk-taking, as suggested by recent theoretical work.

\footnotetext{
${ }^{18}$ However, both types of banks have higher equity ratios than banks from the lowest rating category.
} 


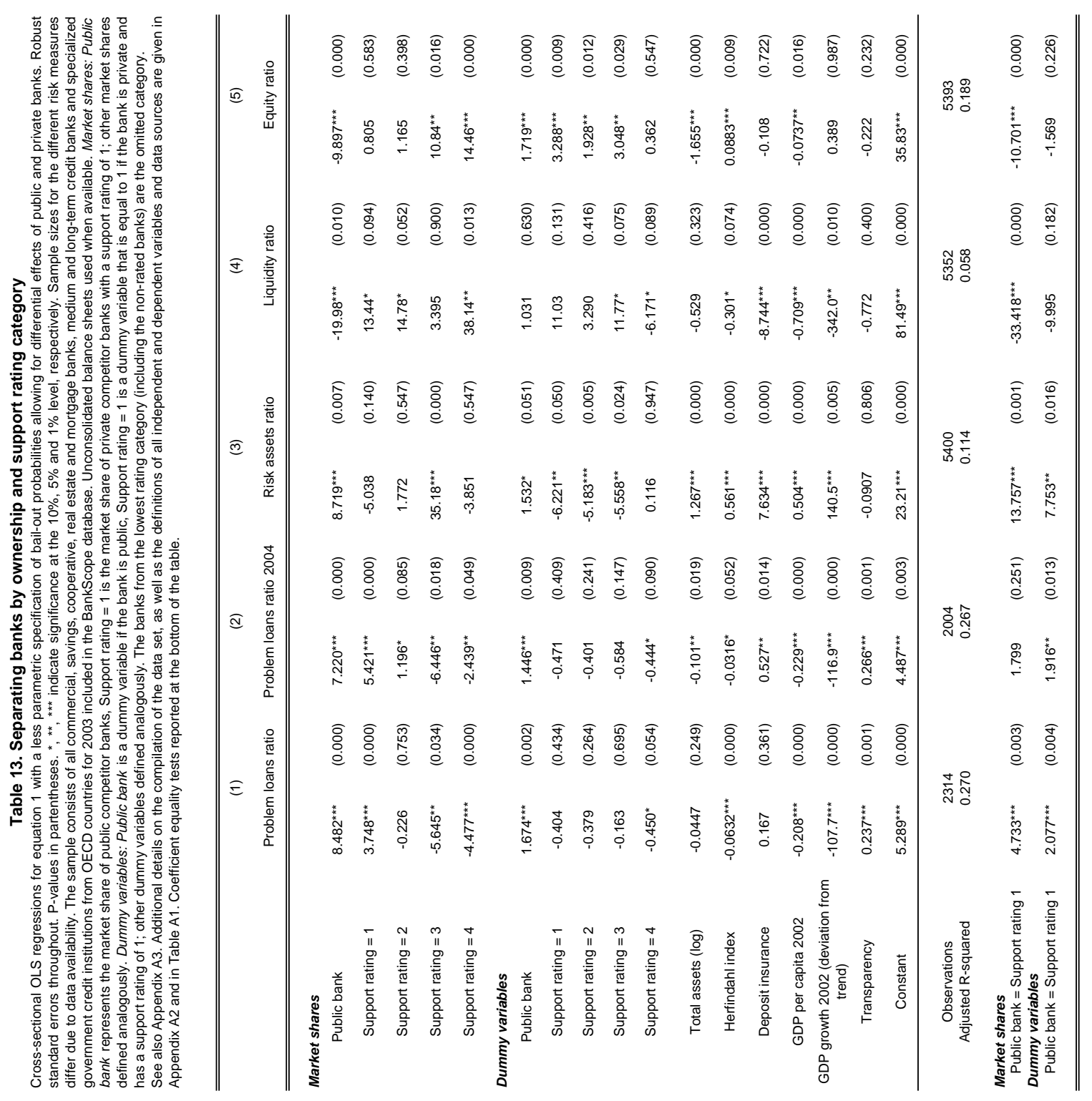


The regression results are striking: $M S I$ significantly increases banks' risk-taking, and the estimated increase in risk is substantial. In contrast, we find no evidence for higher risk-taking at the protected banks themselves, except for banks with outright public ownership. The results prove to be robust to a number of modifications, including the use of a large number of book risk measures and alternative ways of modelling bail-out probabilities and $M S I$. We further show that the effect of $M S I$ indeed runs through the banks' margins. This supports the theoretical prediction that a higher protection of banks reduces margins for competitor banks and pushes these banks towards higher risk-taking.

These results have important policy implications: First, they suggest that the effect of the government guarantees issued during the current financial crisis may constitute a threat to the stability of banking systems in the future. The channel is not moral hazard at the protected banks, as is frequently argued, but rather competitive conduct. The main costs of implicit or explicit government guarantees appear to consist in higher risktaking of competitor banks, rather than of the protected banks themselves. Moreover, the focus on the distortionary effect of explicit guarantees (especially to public banks) may be overly narrow; even though such guarantees have been shown to cause a strong increase in the competitor banks' risk-taking, implicit guarantees also seem to cause distortions. The paper suggests that the public disinvestment and the discontinuation of explicit guarantees may be insufficient to eliminate the distortionary effect of these guarantees: As long as markets continue to expect banks to be bailed out in case of difficulties, the competitive distortions may persist. 


\section{Appendix}

\section{A1. Stylized model}

Setting. In order to derive testable hypotheses, we present a stylized partial equilibrium model in this section. This model is a boiled-down version of Hakenes and Schnabel (2009). Consider a banking system that is characterized by competition for funds à la Monti-Klein. Each single bank faces an upward-sloping supply curve for funding. The gross funding rate (including principal) is $R=R(l, L)$, where $l$ is the bank's demand for funds and $L$ is the bank's competitors' demand for funds. For the purpose of illustration, consider a linear bank-individual supply function, $R=R_{0}+a_{1} l+a_{2} L$ with positive $a_{1}$ and $a_{2}$. The bank invests into risky assets, such as loans. Assume that the bank's portfolio yields $y$ with probability $q(y)$, and zero otherwise (as in Allen and Gale, 2004). Banks are subject to limited liability. As an example, consider a linear risk profile, $q(y)=q_{0}-b y$ with positive $b$ and $q_{0} \cdot{ }^{19}$ A bank's default probability is thus $d=1-q(y)$. Assume for simplicity that investors are not covered by deposit insurance. However, a bank is bailed out by the state with probability $p$ when the bank's portfolio returns nothing. The total default probability is then $d(1-p)$, as in (4). If a bank is fully protected $(p=1)$, its investors are always repaid, hence they do not care about the bank's risk-taking. The supply of funds if then given by $R(l, L)$ as above. However, if the bank is less than fully protected $(p<1)$, investors demand a markup, and the risk-adjusted funding rate becomes $\phi R(l, L)$ with $\phi=(1-d(1-p))^{-1}$ in case of risk neutral investors. ${ }^{20}$

\footnotetext{
${ }^{19}$ By assumption, $q(y)$ does not depend on $l$ and $L$, implying that a bank's risk profile is independent of the loan volume. In reality, if a bank tried to expand its loan volume, it would have to lend to less creditworthy borrowers, hence its portfolio would deteriorate. Then the effect of government guarantees may be even more harmful for competitor banks. In addition, protected banks may poach the best customers from their competitors, leading to a further deterioration of the competitors' loan portfolios. We thank an anonymous referee for pointing out this additional channel, which is ruled out in this model.

${ }^{20}$ For a detailed discussion of assumptions, see Hakenes and Schnabel (2009).
} 
The time structure is fairly standard: At date $t=0$, a bank borrows funds $l$ from investors. Investors anticipate the bank's risk choice $y$ and set $\phi$ accordingly, depending on whether the bank enjoys protection by the state or not. Then, the bank invests into the loan portfolio and chooses $y$. Since $y$ is unobservable, the bank faces a moral hazard problem. As is common in models with risk shifting, each bank takes excessive risks at the expense of investors. At date $t=1$, the portfolio yields $y$ with probability $q(y)$. If their portfolio fails, banks repay only if they are bailed out.

Figure 1 shows the timing of the model.

Figure 1: Time Structure

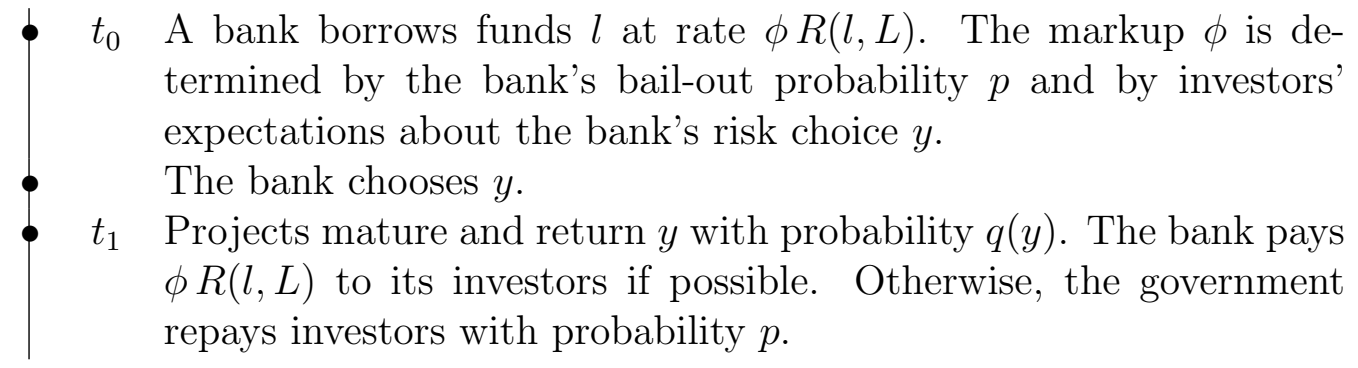

Partial Equilibrium and Comparative Statics. Consider date $t=0$ when the bank determines its risk choice $y$ and its funding volume $l$, which at the same is the volume of its asset portfolio. The bank's profit function is

$$
\begin{aligned}
\Pi & =l q(y)[y-\phi R(l, L)] \\
& =l\left(q_{0}-b y\right)\left[y-\phi\left(R_{0}+a_{1} l+a_{2} L\right)\right] .
\end{aligned}
$$

The first-order conditions with respect to $y$ and $l$ are

$$
\begin{aligned}
& \frac{\partial \Pi}{\partial y}=l\left(q_{0}+b\left(\phi\left(R_{0}+a_{1} l+a_{2} L\right)-2 y\right)\right)=0, \\
& \frac{\partial \Pi}{\partial l}=\left(q_{0}-b y\right)\left(y-\phi\left(R_{0}+2 a_{1} l+a_{2} L\right)\right)=0 .
\end{aligned}
$$


Solving (10) for $y$ yields $y=\phi\left(R_{0}+2 a_{1} l+a_{2} L\right)$. Substituting this expression into (9), one obtains $q_{0}-b \phi\left(R_{0}+3 a_{1} l+a_{2} L\right)=0$. Solving for $l$ yields $l^{*}$, and substituting this into (10) yields $y^{*}$,

$$
l^{*}=\frac{1}{3 a_{1}}\left(\frac{q_{0}}{b \phi}-\left(a_{2} L+R_{0}\right)\right) \quad \text { and } \quad y^{*}=\frac{1}{3}\left(\frac{2 q_{0}}{b}+\phi\left(a_{2} L+R_{0}\right)\right) .
$$

Our results now obtain immediately. The first result concerns the effect of public bail-out guarantees on the protected bank's risk-taking. Hence, it refers to the effect of $p_{i j}$ on Risk $_{i j}$ in equation (1).

Result 1 The relation between a bank's protection $p$ and its risk choice $y$ is ambiguous.

To see this, consider the derivative $\partial y^{*} / \partial \phi$, which is given by

$$
\frac{\partial y^{*}}{\partial \phi}=\frac{1}{3} \cdot \frac{\partial}{\partial \phi}\left(\frac{2 q_{0}}{b}+\phi\left(a_{2} L+R_{0}\right)\right)=\frac{a_{2} L+R_{0}}{3}
$$

This expression can be positive or negative, implying that a higher markup (corresponding to a lower bail-out probability) may result in a risk decrease or a risk increase. This can be demonstrated in two ways. First, we have assumed that $R(l, L)=R_{0}+a_{1} l+a_{2} L$ is the bank-individual deposit supply function. In reality, the supply will not be linear, so $R(l, L)$ can be seen as an approximation in the relevant range. However, the intercept of a linear approximation can be negative, even if the original function is always positive (take the approximation of the function $f(x)=1+x^{2}$ around $x=1$ as an example). For a second related argument, consider the bank-individual elasticity of the inverse supply function,

$$
\begin{aligned}
\varepsilon & =\frac{R\left(l^{*}\right)}{l R^{\prime}\left(l^{*}\right)}=\frac{R_{0}+a_{1} l^{*}+a_{2} L}{a_{1} l^{*}}=\frac{R_{0}+a_{1} \frac{1}{3 a_{1}}\left(\frac{q_{0}}{b \phi}-\left(a_{2} L+R_{0}\right)\right)+a_{2} L}{a_{1} \frac{1}{3 a_{1}}\left(\frac{q_{0}}{b \phi}-\left(a_{2} L+R_{0}\right)\right)} \\
& =\frac{3\left(R_{0}+a_{2} L\right)+\left(\frac{q_{0}}{b \phi}-\left(a_{2} L+R_{0}\right)\right)}{\left(\frac{q_{0}}{b \phi}-\left(a_{2} L+R_{0}\right)\right)}=\frac{q_{0}+2 b \phi\left(a_{2} L+R_{0}\right)}{q_{0}-b \phi\left(a_{2} L+R_{0}\right)},
\end{aligned}
$$


which exceeds 1 if and only if $a_{2} L+R_{0}>0$. Hence, the reaction of a bank's risk choice to government protection $(p)$ depends on whether its individual supply of funds is elastic or not. Since the supply of funds can be elastic or inelastic in reality, the effect of government protection on a bank's risk choice $y$ is ambiguous.

The second result concerns the effect of public bail-out guarantees on the competitor banks' risk-taking, i. e., the effect of $M S I_{-i j}$ on Risk $_{i j}$ in equation (1).

Result 2 A bank's risk choice y depends positively on the protection of its competitors.

The argument is made in three steps. First, higher government protection induces protected banks to expand. Second, this leads to fiercer competition for the bank's competitor banks. Third, a competitor bank that faces stronger competition chooses higher risk.

For the first argument, consider (11). Since the derivative of $l^{*}$ with respect to $\phi$ is negative, a more highly protected bank (with lower $\phi$, e.g. $\phi=1$ ) has a larger optimal funding volume $l^{*}$. The expansion of protected banks implies that $L$ increases, leading to stronger competition for funds. Finally,

$$
\frac{\partial y^{*}}{\partial L}=\frac{1}{3} \cdot \frac{\partial}{\partial L}\left(\frac{2 q_{0}}{b}+\phi\left(a_{2} L+R_{0}\right)\right)=\frac{\phi a_{2}}{3 b}>0
$$

implying that a bank takes more risk when competition intensifies. Taken together, this leads to the conclusion that a higher protection of some banks induces the competitor banks to increase their risk.

\section{A2. Compilation of data set}

Our data set includes all banks from OECD countries contained in the BankScope database in the year 2003. We use unconsolidated bank statements (Bankscope consolidation codes 
$\mathrm{U} 1, \mathrm{U} 2)$ where such statements are available. $\mathrm{U}^{*}$ statements were used only if no other unconsolidated statements existed. If no unconsolidated statements were available, we used consolidated statements $\left(\mathrm{C} 1, \mathrm{C} 2, \mathrm{C}^{*}\right)$. Banks with a consolidation status of $\mathrm{A} 1$ were dropped. ${ }^{21}$ From the remaining banks, we dropped central banks, investment banks and securities houses, multi-lateral governmental banks, as well as non-banking credit institutions. We also dropped bank holdings and bank holding companies to avoid a double-counting of banks. The total assets of all banks in each country in our data set are similar to the data given by the OECD. For internal consistency, we prefer to use the data constructed from our data set. The identification of public ownership and subsidiaries is done on the basis of the information on the ultimate owner contained in the BankScope data set. The given information was complemented through an extensive internet search. The data set is complemented by rating information from Fitch/IBCA (referring to the end of 2002).

\footnotetext{
${ }^{21}$ The BankScope definitions of the different types of bank statements are as follows. U1: a statement not integrating the possible subsidiaries of the concerned bank, and there does not exist a consolidated statement for the bank in the database. U2: a statement not integrating the possible subsidiaries of the concerned bank, and there does exist a consolidated statement in the database. C1: a statement of a mother company integrating the statements of its subsidiaries, and the unconsolidated statement for the bank is not in the database. C2: a statement of a mother company integrating the statements of its subsidiaries, and the unconsolidated statement for the bank is in the database. A1: a statement made up of the addition of the individual statements of a group of affiliated banks. $\mathrm{C}^{*}$ and $\mathrm{U}^{*}$ represent other consolidated or unconsolidated statements, respectively.
} 


\section{A3. A flexible specification of bail-out probabilities}

For simplicity, let us consider the case of just two support rating categories (represented by the dummy variables $D_{1 i}$ and $D_{2 i}$. . We omit country indices and consider a model without a constant term. We ignore further control variables and start from a simplified version of equation (1).

$$
\begin{aligned}
\operatorname{Risk}_{i} & =\alpha_{1} \cdot p_{i}+\alpha_{2} \cdot M S I_{-i}+\epsilon_{i}, \text { where } \\
p_{i} & =p_{1} \cdot D_{1 i}+p_{2} \cdot D_{2 i} \text { and } \\
M S I_{-i} & =p_{1} \cdot \frac{A_{1,-i}}{A}+p_{2} \cdot \frac{A_{2,-i}}{A} .
\end{aligned}
$$

The last equation implies that $M S I$ is a weighted average of the bail-out probabilities of banks from the two rating categories, weighted by the respective market shares (not including the bank itself). Substitution yields

$$
\begin{aligned}
\text { Risk }_{i} & =\alpha_{1} \cdot\left(p_{1} \cdot D_{1 i}+p_{2} \cdot D_{2 i}\right)+\alpha_{2} \cdot\left(p_{1} \cdot \frac{A_{1,-i}}{A}+p_{2} \cdot \frac{A_{2,-i}}{A}\right)+\epsilon_{i} \\
& =\delta_{1} \cdot D_{1 i}+\delta_{2} \cdot D_{2 i}+\delta_{3} \cdot \frac{A_{1,-i}}{A}+\delta_{4} \cdot \frac{A_{2,-i}}{A}+\epsilon_{i} .
\end{aligned}
$$

The $\delta$-parameters can be estimated by a regression of Risk on the rating category dummy variables plus the respective market shares. However, it is not possible to infer the parameters of interest, i. e., in particular $\alpha_{2}$, from the estimated coefficients. Therefore, we impose the restriction that the bail-out probability of the most highly protected bank group is equal to one. Note that this restriction is much milder than assigning bail-out probabilities to all rating categories.

We see directly that $\alpha_{2}$ is then equal to $\delta_{3}$. Hence, we can simply look at the coefficient of the market share of the highest rating category in order to infer the effect of $M S I$ on banks' risk-taking. An analogous argument can be made with respect to $\alpha_{1}$ and $\delta_{1}$. 
Note that in the actual estimation, we treat the lowest rating class (including the nonrated banks) as the omitted category. 


\section{A4. Appendix tables}

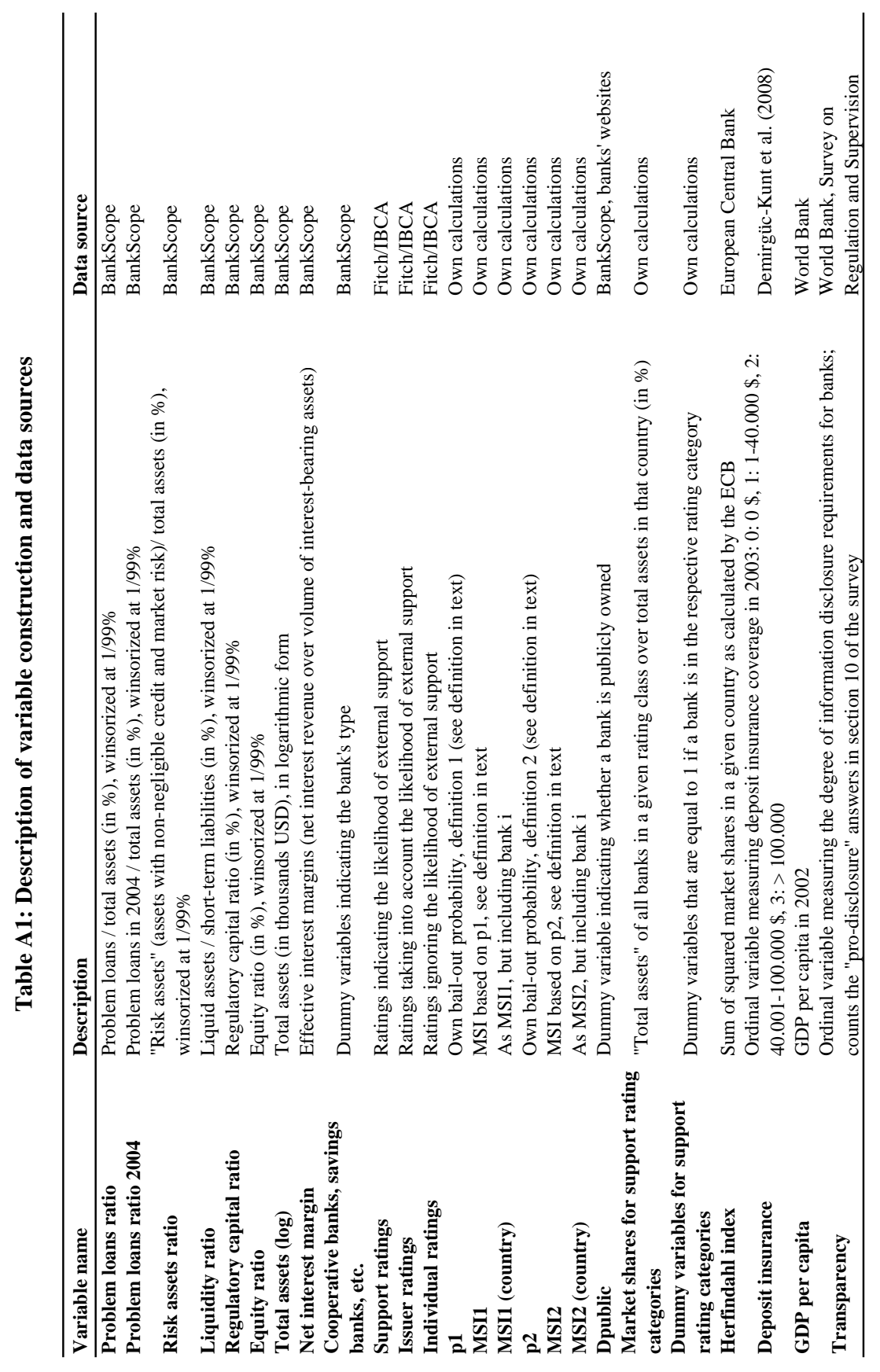


Table A2. Instrumental variable model for MSI1 with bank type fixed effects

Instrumental variable model. Estimated using equations (6) and (7) with bank type dummies added (not reported). Panel A reports the results for the first stage and panel $B$ for the second stage. The dependent variable in the first stage is the net interest margin. The dependent variable in the second stage are the same risk measures as before. Robust standard errors throughout. P-values in parentheses. *, **, *** indicate significance at the $10 \%, 5 \%$ and $1 \%$ level, respectively. Sample sizes for the different risk measures differ due to data availability. The sample consists of all commercial, savings, cooperative, real estate and mortgage banks, medium and long-term credit banks and specialized government credit institutions from OECD countries for 2003 included in the BankScope database. Unconsolidated balance sheets used when available. MSI1 is the market share of insured competitor banks as defined in the text. Additional details on the compilation of the data set, as well as the definitions of all independent and dependent variables and data sources are given in Appendix A2 and Table A1.

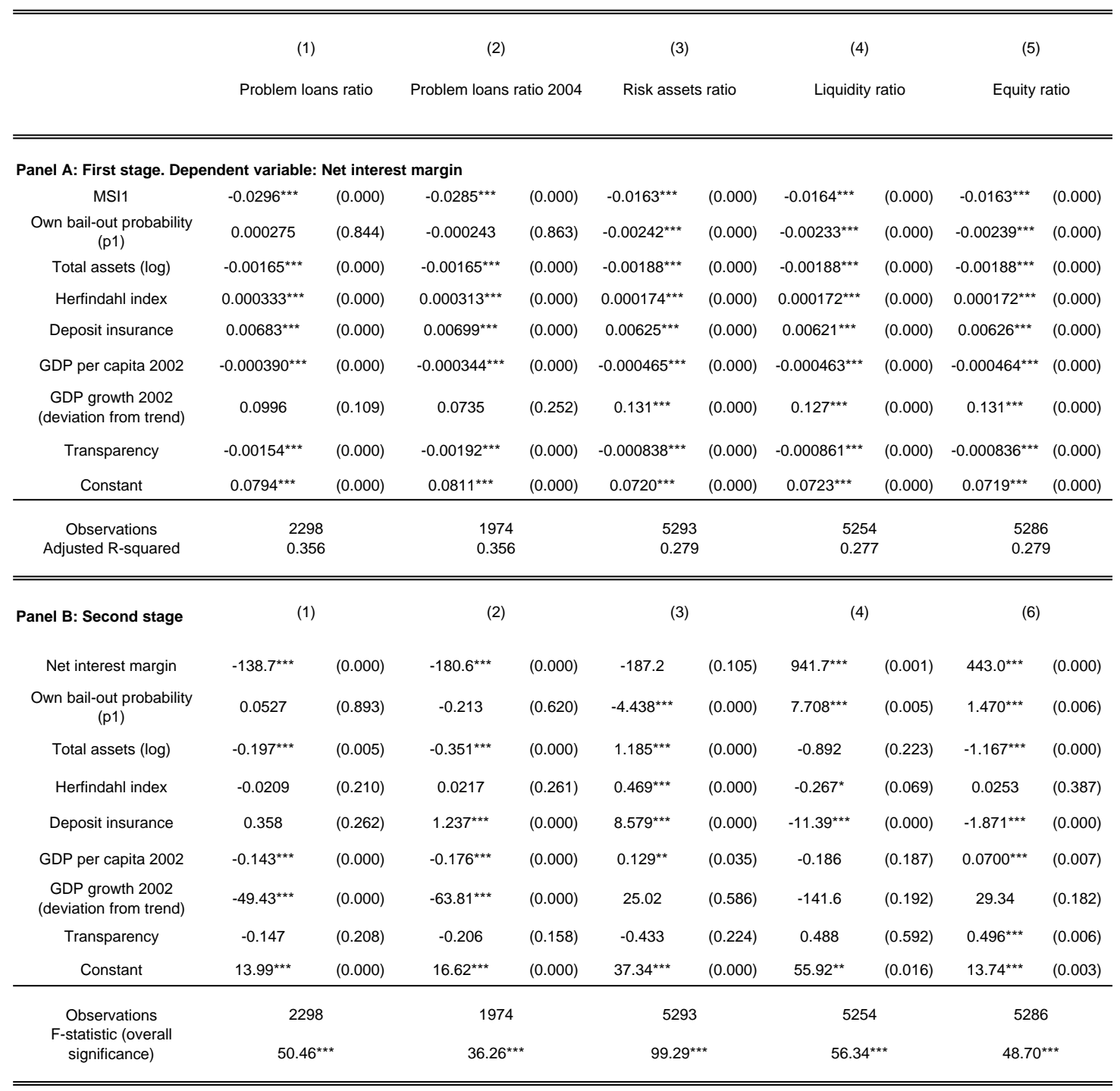




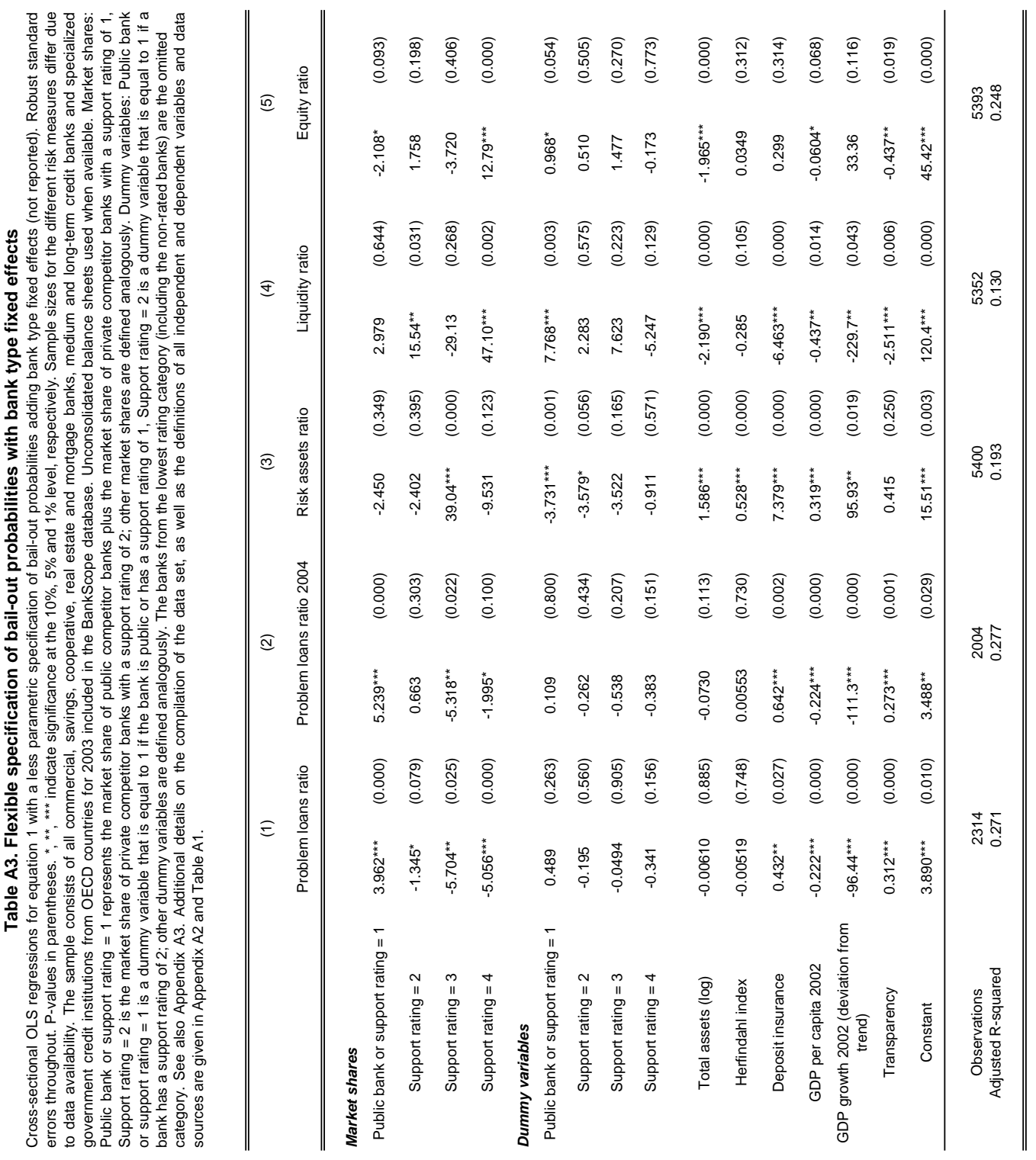




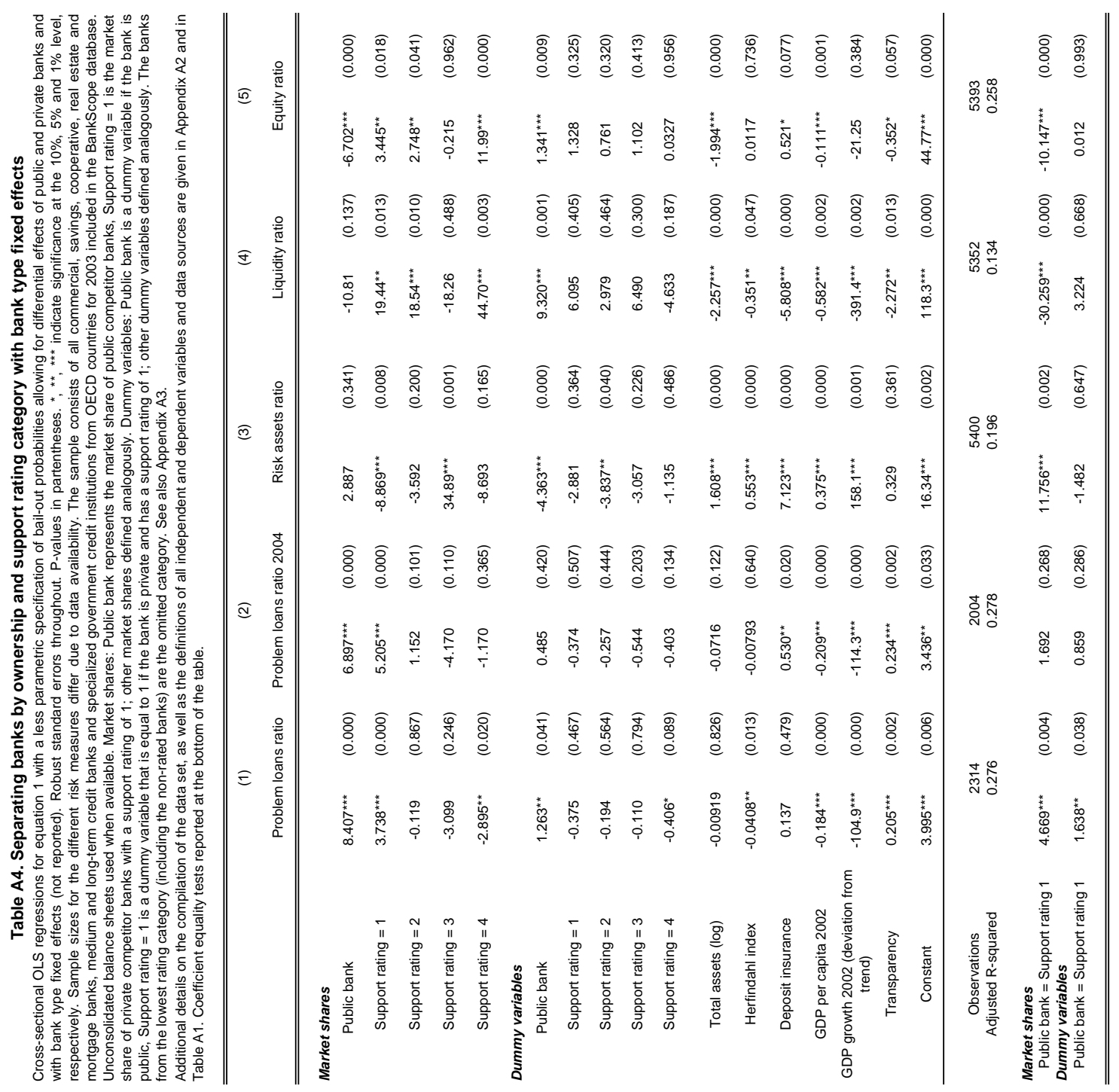




\section{References}

Allen, Franklin and Douglas Gale (2004): "Competition and Financial Stability," Journal of Money, Credit and Banking, 36(3) Pt. 2, 453-480.

Barth, James R., Gerard Caprio, and Ross Levine (2004): "Bank Regulation and Supervision: What Works Best?," Journal of Financial Intermediation, 13, 205-248.

Beck, Thorsten, Asli Demirgüç-Kunt, and Ross Levine (2006): "Bank Concentration and Crises: First Results," Journal of Banking and Finance, 30, 1581-1603.

Borio, Claudio, Craig Furfine, and Philip Lowe (2001): "Procyclicality of the financial system and financial stability: issues and policy options," BIS Papers No. 1.

Boyd, John H. and Mark Gertler (1994): "The Role of Large Banks in the Recent U.S. Banking Crisis," Federal Reserve Bank of Minneapolis Quarterly Review, 18(1), 2-21.

Boyd, John H. and David E. Runkle (1993): "Size and Performance of Banking Firms: Testing the Predictions of Theory," Journal of Monetary Economics, 31(1), 47-67.

Caprio, Gerard and Maria Soledad Martinez Peria (2000): "Avoiding Disaster: Policies to Reduce the Risk of Banking Crises," Egyptian Center for Economic Studies, Working Paper, No. 47.

Cordella, Tito and Eduardo L. Yeyati (2003): "Bank Bailouts: Moral Hazard vs. Value Effect," Journal of Financial Intermediation, 12, 300-330.

Demirgüç-Kunt, Asli and Enrica Detragiache (2002): "Does Deposit Insurance Increase Banking System Stability? An Empirical Investigation," Journal of Monetary Economics, 49(7), 1373-1406. 
Demirgüç-Kunt, Asli, Ed Kane, Baybars Karacaovali and Luc Laeven (2008): "Deposit Insurance around the World: A Comprehensive Database" in: Demirgüç-Kunt, Asli, Ed Kane and Luc Laeven (eds): Deposit Insurance around the World: Issues of Design and Implementation, MIT Press, Cambridge, MA.

Demsetz, Rebecca S. and Philip E. Strahan (1997): "Diversification, Size, and Risk at Bank Holding Companies," Journal of Money, Credit and Banking, 29(3), 300-313.

De Nicoló, Gianni (2001): "Size, Charter Value, and Risk in Banking: An International Perspective," in: The Financial Safety Net: Costs, Benefits and Implications for Regulation, Proceedings of the 37th Annual Conference on Bank Structure and Competition, Federal Reserve of Chicago, 197-215.

De Nicoló, Gianni, Philip Bartholomew, Jahanara Zaham, and Mary Zephirin (2004): "Bank Consolidation, Conglomeration and Internationalization: Trends and Implications for Financial Risk," Financial Markets, Institutions \& Instruments, 13, 173-217.

De Nicoló, Gianni and Elena Loukoianova (2007): "Bank Ownership, Market Structure, and Risk," International Monetary Fund Working Paper No. 07/215, Washington, D.C.

Fitch/IBCA (2005): "Fitch Ratings Global Corporate Finance 2004 Transition and Default Study," available at http://www.fitchratings.com.

Flannery, M. (1998): "Using Market Information in Prudential Banking Supervision: A Review of U.S. Evidence," Journal of Money, Credit and Banking, 30, 273-305.

Furlong, Frederick T. (1988): "Changes in Bank Risk-Taking," Federal Reserve Bank of San Francisco Economic Review, 2, 45-56. 
Gropp, Reint, and Jukka Vesala (2004): "Deposit insurance, moral hazard and market monitoring," Review of Finance, 8(4), 571-602.

Gropp, R., J. Vesala, and G. Vulpes (2006) "Equity and debt market signals as indicators of bank fragility," Journal of Money, Credit, and Banking, 38 (2), 399-428.

Hakenes, Hendrik and Isabel Schnabel (2009): "Banks without Parachutes - Competitive Effects of Government Bail-out Policies, "Journal of Financial Stability, forthcoming.

Hovakimian, Armen and Edward J. Kane (2000): "Effectiveness of Capital Regulation at U.S. Commercial Banks, 1985-1994," Journal of Finance, 55(1), 451-468.

Hyytinen, Ari and Tuomas Takalo (2002): "Enhancing Bank Transparency: A Re-assessment," European Finance Review, 6(3), 429-445.

Kane, Edward J. (1989): The S \& L Insurance Mess: How did it Happen? Washington: Urban Institute Press.

Keeley, Michael C. (1990): "Deposit Insurance, Risk and Market Power in Banking," American Economic Review, 80(5), 1183-1200.

Merton, Robert (1977): "An Analytical Derivation of the Cost of Deposit Insurance and Loan Guarantees," Journal of Banking and Finance, 1(1), 3-11.

OECD (2004): Bank Profitability. Financial Statements of Banks 1994-2003. Edition 2004. Paris.

Rime, Bertrand (2006): "Do 'too big to fail' expectations boost large banks' issuer ratings?", Unpublished Working Paper, Swiss National Bank.

Rosengren, Eric (1999): "Will greater disclosure and transparency prevent the next banking crisis?", in The Asian Financial Crisis: Origins, Implications and Solutions 
by William C. Hunter, George Kaufman, and Thomas Krueger (eds.), Kluwer Academic Publishers.

Sapienza, Paola (2004): "The effects of government ownership on bank lending," Journal of Financial Economics, 72, 357-384.

Schnabel, Isabel (2004): "The German Twin Crisis of 1931," Journal of Economic History, 64(3), 822-871.

Schnabel, Isabel (2009): "The Role of Liquidity and Implicit Guarantees in the German Twin Crisis of 1931," Journal of International Money and Finance, 28, 1-25.

Shrieves, Ronald E. and Drew Dahl (1992): "The Relationship between Risk and Capital in Commercial Banks," Journal of Banking and Finance, 16, 439-457.

Sironi, A. (2003): "Testing for Market Discipline in the European Banking Industry: Evidence from Subordinated Debt Issues," Journal of Money, Credit and Banking, 35(3), 443-472. 